\title{
Splenocyte-Conditioned Media Inhibit Breast Cancer MCF-7 Cell Growth, Associated with Increased Th2/Th1 Cytokine Secretion Ratio in the Media using Five Selected Polysaccharides
}

Hsiao-Chien Lin and Jin-Yuarn Lin*

Department of Food Science and Biotechnology, National Chung Hsing University, Taichung City 402, Taiwan

\begin{abstract}
Aims: To unravel the cause and possible prevention of breast cancer, five potential polysaccharides from guava seed (GSPS), common buckwheat (CBPS), bitter buckwheat (BBPS), red Formosa lambsquarters (RFLPS) and yellow Formosa lambsquarters (YFLPS) were selected to treat human breast cancer MCF-7 cells with direct action or indirect tumor immunotherapy using polysaccharide-treated splenocyte-conditioned media (SCM).

Methods: Five different polysaccharides were partially characterized. Cytokine levels produced by type 1 helper T-cells [Th1; interleukin (IL)-2 and interferon- $\mathrm{Y}$ ] and type 2 helper T-cells (Th2; IL-4, IL-5 and IL-10) in SCM were determined using ELISA. Breast cancer MCF-7 cell viability was determined using an MTT assay. The association between cytokine levels in SCM and the corresponding breast cancer MCF-7 cell viability was investigated using the Pearson product-moment correlation coefficient.

Results: Total carbohydrate and protein contents indicated that these isolated polysaccharides might be proteopolysaccharides or glycoproteins. Molecular weights of purified polysaccharides fractions from the five isolated polysaccharides were determined. All 5 selected crude polysaccharides, in particular GSPS, BBPS and RFLPS, significantly increased IL-10/IL-2 cytokine secretion ratios by splenocytes. Treatment with SCM prepared in the presence or absence of the polysaccharides, but not the direct action of the polysaccharides, significantly inhibited MCF-7 cell viability. GSPS-, BBPS- and RFLPS-treated SCM demonstrated slightly enhanced inhibitory effects against breast cancer MCF-7 cell viability. There were negative correlations between MCF-7 cell viabilities and IL-10 cytokine secretion levels, as well as IL-10/IL-2 cytokine secretion ratios in the corresponding SCM. The present findings suggested that an increased Th2/Th1 cytokine secretion ratio, particularly an increase in IL-10, by immune cells including T lymphocytes, may inhibit MCF-7 cell growth in the tumor microenvironment. GSPS, BBPS and RFLPS may be further applied to treat human breast cancer via tumor immunotherapy by increasing the Th2/ Th1 cytokine secretion ratio.
\end{abstract}

Keywords: MCF-7 Cells; Polysaccharides; Splenocyte-Conditioned Medium; Th1/Th2 Cytokines; Tumor Immunotherapy

\section{Abbreviations \\ BBPS: Bitter Buckwheat Polysaccharide; CBPS: Common Buckwheat Polysaccharide; GSPS: Guava Seed Polysaccharide; IL: Interleukin; RFLPS: Red Formosa Lambsquarters Polysaccharide; SCM: Splenocyte-Conditioned Media; Th1: Type 1 Helper T-cell; Th2: Type 2 Helper T-cell; YFLPS: Yellow Formosa Lambsquarters Polysaccharide.}

\section{Introduction}

Breast cancer is responsible for $7-10 \%$ of malignancies, second only to uterine cancer in women [1,2]. The onset of breast cancer is often hereditary and occurs between 40-60 years of age, resulting in a higher incidence in post-menopausal women $[3,4]$. Breast cancer that occurs in the breast glandular tissue seriously affects women's health and is life threatening $[4,5]$. Therefore, preventing the onset or inhibiting the growth of breast cancer cells is an important healthcare issue. Macroand micro-molecules from food or traditional herbal medicines have previously been studied for their anti-cancer potential, and may provide an alternative option for the treatment of breast cancer [6-9]. Certain polysaccharides or proteins have been demonstrated to have the potential to treat cancers, which may help to advance the treatment of breast cancer. For example, purified protein from the Chinese tartary buckwheat (Fagopyrum tataricum Gaertn.) was previously demonstrated to inhibit the proliferation of human breast cancer Bcap 37 cells [10] and induce apoptosis by downregulating B-cell lymphoma 2 expression and upregulating Fas expression [11]. Wolfberry fruit polysaccharides have been demonstrated to effectively inhibit the growth of human breast cancer MCF-7 cells by inducing G0/G1 phase arrest and apoptosis of the cells [12]. Selenium-enriched polysaccharide extracts inhibit the proliferation of human breast cancer MCF-7 cells by inducing apoptosis and cell cycle arrest in the G2/M phase [13]. Despite these previous studies, the underlying mechanisms of the anti-cancer properties of polysaccharides from fruit seeds and non-traditional cereal crops remain poorly understood. The indigestible property of polysaccharides suggests that cancer immunotherapy via Peyer's patches in small intestine is most possible.

Cancer immunotherapies, including cell-based therapies, antibody therapies and cytokine therapies, are types of immunotherapy which not only directly target the cancer cells, but also indirectly take advantage of the immune cells themselves or their secreted products to enable the

*Corresponding author: Jin-Yuarn Lin, Department of Food Science and Biotechnology, National Chung Hsing University, 145 Xingda Rd., South Dist., Taichung City 402, Taiwan, Tel: 886-4-22851857; Fax: 886-4-22851857; E-mail: jinlin@nchu.edu.tw

Received March 29, 2017; Accepted April 18, 2017; Published April 24, 2017

Citation: Lin HC, Lin JY (2017) Splenocyte-Conditioned Media Inhibit Breast Cancer MCF-7 Cell Growth, Associated with Increased Th2/Th1 Cytokine Secretion Ratio in the Media using Five Selected Polysaccharides. J Immuno Biol 2: 121.doi: 10.4172/2476-1966.1000121

Copyright: (c) 2017 Lin HC, et al. This is an open-access article distributed under the terms of the Creative Commons Attribution License, which permits unrestricted use, distribution, and reproduction in any medium, provided the original author and source are credited. 
treatment of cancer [14,15]. In cell-based therapy, immune cells specific for cancer cells, including natural killer (NK) cells, lymphokineactivated killer cells, cytotoxic T cells and dendritic cells, are activated and grown in vitro or in vivo to provoke immune responses against the cancer [16]. Antibody therapies are the most successful form of immunotherapy and have been approved for the treatment of multiple cancers. Antibody therapy functions by exploiting specific antibodies, produced by $\mathrm{B}$ lymphocytes, to bind to a target antigen on the surface of a cancer cell [17-19]. Cytokine therapies exploit cytokines which have been produced by a number of different cell types present within a tumor, and may modulate the immune response to inhibit the growth of cancer cells. Interferons (IFNs) and interleukins (ILs), particularly IFN- $\alpha$ and IL-2, have been used as drugs to provoke immune responses against tumors [20-23]. Among macromolecules, $\beta$-glucans, including lentinan compounds, have been demonstrated to possess anti-cancer properties by stimulating macrophages, NK cells, T cells and cytokine secretion $[6,8]$. The polysaccharides from mushroom Trametes versicolor extract are suggested as dietary supplements to enhance the immune system of patients undergoing chemotherapy [24]. Polysaccharides demonstrating diverse immunomodulatory activities, particularly those with anti-inflammatory potential, have been suggested to have the potential to treat cancer via tumor immunotherapy $[7,9,25,26]$. However, the association between active polysaccharides and tumor immunotherapy is poorly understood.

To investigate the potential effects of different polysaccharides on breast cancer cell growth, 5 selected polysaccharides from guava seed, common buckwheat, bitter buckwheat, red Formosa lambsquarters and yellow Formosa lambsquarters were selected to treat human breast cancer MCF-7 cells via direct addition and indirect tumor immunotherapy using splenocyte-conditioned media (SCM). These polysaccharides exhibiting diverse immunomodulatory activities, particularly antiinflammatory potential, were selected based on previous scientific and technical literature $[10,11,27,28]$. The association between breast cancer MCF-7 cell growth and type 1 helper T-cell (Th1)/type 2 helper T-cell (Th2) cytokine secretion profiles in the corresponding SCM in the absence or presence of selected polysaccharides were investigated.

\section{Materials and Methods}

\section{Isolation of selected crude polysaccharides}

Briefly, samples of air-dried guava (Psidium guajava Linn) seed, common buckwheat (Fagopyrum esculentum), bitter buckwheat (Fagopyrum leptopodum), red Formosa lambsquarters (Chenopodium formosanum) and yellow Formosa lambsquarters (Chenopodium formosanum) were individually ground to a powder. The lipids in the powder samples were removed using $n$-hexane (1:4, weight/volume) for $4 \mathrm{~h}$ to avoid disturbance in the following polysaccharide isolation procedure. Aliquots of $50 \mathrm{~g}$ powder samples were added to 250 or 500 $\mathrm{ml}$ deionized water, respectively, and agitated at room temperature for $4 \mathrm{~h}$. Following centrifugation at $4^{\circ} \mathrm{C}, 5,000 \times \mathrm{g}$ for $30 \mathrm{~min}$, the supernatant was collected, measured and three volumes of $95 \%$ ethyl alcohol were volumetrically added. The mixtures were slowly agitated at $4^{\circ} \mathrm{C}$ for $12 \mathrm{~h}$ to precipitate the polysaccharide fractions, and centrifuged at $25^{\circ} \mathrm{C}, 5,000 \times \mathrm{g}$ for $30 \mathrm{~min}$ at room temperature to separate the insoluble polysaccharides from the supernatant. The polysaccharide pellet was then lyophilized for use. Isolated crude polysaccharides, including guava seed polysaccharides (GSPS), common buckwheat polysaccharides (CBPS), bitter buckwheat polysaccharides (BBPS), red Formosa lambsquarters polysaccharides (RFLPS) and yellow Formosa lambsquarters polysaccharides (YFLPS), were obtained for the following experiments [28].

\section{Characterization of five selected polysaccharide fractions}

To partially characterize the polysaccharide fractions the UV-Vis absorption spectra of the five selected polysaccharide fractions were recorded. Total sugar and protein contents in the isolated GSPS, CBPS, BBPS, RFLPS and YFLPS were measured. The carbohydrate contents in the GSPS, CBPS, BBPS, RFLPS and YFLPS samples were analyzed using the phenol-sulfuric acid method [29]. Briefly, the reaction mixture absorbance was measured at $492 \mathrm{~nm}$ against a deionized water blank using glucose as a standard. The protein contents of the polysaccharide samples were analyzed using the bicinchoninic acid (BCA) protein assay kit (Pierce; Thermo Fisher Scientific, Inc., Waltham, MA, USA) [30], according to the manufacturer's protocol with a 96-well microtiter plate. Briefly, the reaction mixture absorbance was measured at $550 \mathrm{~nm}$ against a deionized water blank using bovine serum albumin (BSA) as a standard. Additionally, each individual crude polysaccharide was resolved into 2-3 identified sub-fractions in a Sepharose 6B gel (Sigma-Aldrich; Merck KGaA, Darmstadt, Germany) filtration chromatography column eluting with deionized water [26]. Molecular weights of identified sub-fractions were determined by calibrating with a standard compound (blue dextran, $\mathrm{MW}=2,000 \mathrm{kDa}$, Sigma-Aldrich; Merck KGaA) and protein molecular weight standards kit (MWGF 1000 kit, MW: 6,500-670,000 Da, Sigma-Aldrich; Merck KGaA) using the Sepharose 6B gel filtration column $[26,28]$.

\section{Isolation of mouse primary splenocytes}

A total of fifty female BALB/cByJNarl mice (8 weeks old, 20 g body weight) were purchased from the National Applied Research Laboratories, National Science Council (Taipei, Taiwan). The experimental mice were maintained in the Department of Food Science and Biotechnology at National Chung Hsing University, College of Agriculture and Natural Resources (Taichung, Taiwan). The mice were provided a chow diet (laboratory standard diet) and water ad libitum. All mice were housed in stainless steel cages and kept at a controlled temperature $\left(25 \pm 2^{\circ} \mathrm{C}\right)$ and ambient humidity $(50-75 \%)$. Lights were maintained on a $12 \mathrm{~h}$ light-dark cycle. The protocol of the present study was reviewed and approved by the Institutional Animal Care and Use Committee (approval no. 101-95), National Chung Hsing University (Taichung, Taiwan).

Following accommodation for 2 weeks, the experimental mice (10 weeks old) were anaesthetized with isoflurane (cat. no., 49001605, Panion and BF Biotech Inc., Taipei, Taiwan) using a vaporizer (CAS-01, Northern Vaporiser Limited, Cheshire, England, UK), bled by puncturing the retro-orbital venous plexus, and then immediately sacrificed with $\mathrm{CO}_{2}$ to isolate primary splenocytes. The spleens were aseptically removed from the BALB/c mice, homogenized in tissue culture medium (TCM, a serum replacement; Celox Laboratories Inc. Lake Zurich, IL), and suspended in a medium consisting of $10 \mathrm{ml}$ TCM, $500 \mathrm{ml}$ RPMI 1640 medium (Atlanta Biologicals, Inc., Flowery Branch, GA), and $2.5 \mathrm{ml}$ antibiotic-antimycotic solution $(100 \mathrm{x})$ containing 10,000 U/ml penicillin, $10 \mathrm{mg} / \mathrm{ml}$ streptomycin and $25 \mu \mathrm{g} /$ $\mathrm{ml}$ amphotericin B in $0.85 \%$ saline (Atlanta Biologicals, Inc.). Single splenocytes were collected and treated with red blood cell (RBC) lysis buffer [0.017 M Trizma base (Sigma-Aldrich; Merck KGaA), 0.144 M ammonium chloride (Sigma-Aldrich; Merck KGaA), pH 7.4, $0.20 \mu \mathrm{m}$ filtered] to lyse the RBCs. Splenocytes isolated from each animal were adjusted to a concentration of $1 \times 10^{7}$ cells $/ \mathrm{ml}$ in TCM medium with a hemocytometer using trypan blue dye for subsequent experiments [31]. Isolated mouse primary splenocytes are composed of $41.54 \% \mathrm{~B}$ cells and $47.11 \% \mathrm{~T}$ cells, as well as trace amounts of macrophages and 
dendritic cells, and have therefore been suggested to be a suitable in vitro model to reflect the status of whole immune responses in vivo [32].

\section{Determination of optimal concentrations of selected crude polysaccharides to mouse primary splenocytes}

To avoid cytotoxicity, the viabilities of splenocytes treated with different concentrations of GSPS, CBPS, BBPS, RFLPS and YFLPS were determined. Each splenocyte population $\left(5 \times 10^{6}\right.$ cells $/ \mathrm{ml}$ TCM medium; $50 \mu \mathrm{l} /$ well) was respectively treated with GSPS, CBPS, BBPS, RFLPS and YFLPS at the indicated concentrations of $0,1.6$ $8,40,200,500$ and $1,000 \mu \mathrm{g} / \mathrm{ml} \mathrm{TCM} \mathrm{medium} \mathrm{(50 \mu l/well),} \mathrm{as} \mathrm{well}$ as lipopolysaccharide (LPS; Sigma-Aldrich; Merck Millipore), as a positive control, at $2.5 \mu \mathrm{g} / \mathrm{ml}$ in 96 well micro titer plates. The plates were incubated at $37^{\circ} \mathrm{C}$ in a humidified incubator with $5 \% \mathrm{CO}_{2}$ and $95 \%$ air for $72 \mathrm{~h}$. Viability of splenocytes was determined using a 3-(4,5-dimethylthiazol-2-diphenyl)-2,5-tetrazolium bromide (MTT, Sigma-Aldrich Co., St. Louis, MO) assay. The absorbance was measured at $550 \mathrm{~nm}$ on an ELISA plate reader (ASYS Hitech GmbH, Eugendorf, Austria). Based on changes in cell viabilities, non-cytotoxic optimal concentrations of the polysaccharide fractions were adopted for the following experiments.

\section{Effects of selected polysaccharides on cytokine secretions by primary splenocyte}

To assess the effects of GSPS, CBPS, BBPS, RFLPS and YFLPS administration on the Th1/Th2 cytokine secretion profiles, polysaccharide samples were added to isolated splenocytes $\left(5 \times 10^{6}\right.$ cells/ml in TCM medium; $0.5 \mathrm{ml} /$ well) at the indicated non-cytotoxic concentrations of $0,1.6,8,40$ and $200 \mu \mathrm{g} / \mathrm{ml}$ GSPS, CBPS, BBPS, RFLPS or YFLPS, or LPS at $2.5 \mu \mathrm{g} / \mathrm{ml}$ (as a positive control) in 24-well plates. The plates were incubated at $37^{\circ} \mathrm{C}$ in a humidified incubator with $5 \%$ $\mathrm{CO}_{2}$ and $95 \%$ air for $48 \mathrm{~h}$. The culture plates were then centrifuged at $25^{\circ} \mathrm{C}, 400 \times \mathrm{g}$ for $10 \mathrm{~min}$. The supernatants in the cell cultures were collected and stored at $-80^{\circ} \mathrm{C}$ for cytokine assays. Th1 (IL-2, IFN- $\gamma$ ) and Th2 (IL-4, IL-5, IL-10) cytokine secretion levels in the splenocyte cultures were measured using an enzyme-linked immunosorbent assay (ELISA) as described below.

Preparation of splenocyte-conditioned media (SCM) by using 5 selected crude polysaccharides. To clarify whether immune cell secretions influence cancer cell growth, conditioned media of splenocytes cultured with GSPS, CBPS, BBPS, RFLPS and YFLPS were collected to administer to human breast MCF-7 cancer cells, respectively. Isolated splenocytes $\left(5 \times 10^{6}\right.$ cells $/ \mathrm{ml} \mathrm{TCM}$ medium; 0.5 $\mathrm{ml} /$ well) with GSPS, CBPS, BBPS, RFLPS and YFLPS at the indicated non-cytotoxic concentrations of $0,1.6,8,40$ and $200 \mu \mathrm{g} / \mathrm{ml}$ TCM medium $(0.5 \mathrm{ml} /$ well $)$ were cultured in 24 well plates. The plates were incubated at $37^{\circ} \mathrm{C}$ in a humidified incubator with $5 \% \mathrm{CO}_{2}$ and $95 \%$ air for $48 \mathrm{~h}$. The culture plate was centrifuged at $25^{\circ} \mathrm{C}, 400 \times \mathrm{g}$ for 10 min. The supernatants $(1.0 \mathrm{ml} /$ well $)$ in the cell cultures were collected, measured volumetrically and lyophilized. The SCM lyophilized powder was dissolved in $0.5 \mathrm{ml}$ of MEM/EBSS medium consisting of minimum essential medium (MEM) with Earle's balanced salts (MEM/EBSS; SH30024.02; Hyclone, Logan, UT, USA) supplemented with $10 \%$ fetal bovine serum (FBS; 04-001-1A; Biological Industries, Kibbutz BeitHaemek, Israel), $0.1 \mathrm{mM}$ non-essential amino acids, $1.0 \mathrm{mM}$ sodium pyruvate, $100 \mathrm{U} / \mathrm{ml}$ penicillin, $100 \mu \mathrm{g} / \mathrm{ml}$ streptomycin and $0.25 \mu \mathrm{g} / \mathrm{ml}$ amphotericin B. The two-fold concentrated SCM was stored at $-80^{\circ} \mathrm{C}$ until use.

\section{Culture of human breast cancer MCF-7 cell}

Human breast cancer MCF-7 cells were obtained from the Bioresource Collection and Research Center, Food Industry Research and Development Institute (Hsinchu, Taiwan). The breast cancer MCF7 cells were defrosted at $37^{\circ} \mathrm{C}$ and maintained in MEM/EBSS medium at $37^{\circ} \mathrm{C}$ in a humidified incubator with $95 \%$ air and $5 \% \mathrm{CO}_{2}$. When grown to $90 \%$ confluence in a $75 \mathrm{~T}$ tissue culture flask (TPP Techno Plastic Products AG, Trasadingen, Switzerland), the cells were plated at a density of $2 \times 10^{5}$ cells $/ \mathrm{ml}$ in the 96 -well plates to perform the following bio-assay.

\section{Effects of direct administrations of 5 different crude polysaccharides on the growth of breast cancer MCF-7 cells}

To evaluate the direct action of selected polysaccharides on the growth of MCF-7 cells, $50 \mu \mathrm{l} /$ well MCF-7 cells $\left(2 \times 10^{5}\right.$ cells $\left./ \mathrm{ml}\right)$ were treated with GSPS, CBPS, BBPS, RFLPS and YFLPS (50 $\mu \mathrm{l} /$ well) at the indicated concentrations of $0,1.6,8,40$ and $200 \mu \mathrm{g} / \mathrm{ml}$ in MEM/EBSS medium, as well as $2.5 \mu \mathrm{M}$ paclitaxel (T-7402; Sigma-Aldrich; Merck $\mathrm{KGaA}$; as a positive control). The plates were incubated for 24 or 48 h. The viability of breast cancer MCF-7 cells was determined using an MTT assay as described below. In the present study, paclitaxel was selected as a positive control to compare the polysaccharide effects against MCF-7 cell growth. Paclitaxel, a natural product from Yew trees, has been considered a powerful chemotherapeutic drug for the treatment of a number of types of cancer, including breast, ovary and prostate cancer, esophageal and non-small cell lung carcinoma, and melanoma [33].

\section{Effect of SCM administrations on the viability of MCF-7 cells}

To evaluate the effects of tumor immunotherapy on MCF-7 cell growth, $50 \mu \mathrm{l} /$ well MCF-7 cells $\left(2 \times 10^{5}\right.$ cells $\left./ \mathrm{ml}\right)$ were treated with 50 $\mu \mathrm{l} /$ well SCM, as well as paclitaxel (as a positive control) at $2.5 \mu \mathrm{M}$. The plates were incubated in a humidified incubator with $5 \% \mathrm{CO}_{2}$ and $95 \%$ air at $37^{\circ} \mathrm{C}$ for 24 or $48 \mathrm{~h}$. The remaining cells were measured using an MTT assay as described below.

\section{Measurement of cell viabilities using MTT assay}

Following incubation, $10 \mu \mathrm{l}$ aliquots of $5 \mathrm{mg} / \mathrm{ml}$ MTT (SigmaAldrich Co.) in phosphate-buffered saline (PBS, $137 \mathrm{mM} \mathrm{NaCl}, 2.7$ $\mathrm{mM} \mathrm{KCl}, 8.1 \mathrm{mM} \mathrm{Na}_{2} \mathrm{HPO}_{4}, 1.5 \mathrm{mM} \mathrm{KH}_{2} \mathrm{PO}_{4}, \mathrm{pH} 7.4,0.20 \mu \mathrm{m}$ filtered) were added to the cells in each well of the 96 -well plate. The plate was incubated at $37^{\circ} \mathrm{C}$ for another $4 \mathrm{~h}$. The plate was centrifuged at $25^{\circ} \mathrm{C}$, $400 \times \mathrm{g}$ for $10 \mathrm{~min}$ and the culture medium was discarded. The plate was carefully washed with PBS buffer 3 times. Aliquots of $100 \mu \mathrm{l}$ dimethyl sulfoxide were added to each well and oscillated for $30 \mathrm{~min}$ to extract the insoluble formazan. The absorbance (A) was measured at $550 \mathrm{~nm}$ on an ELISA plate reader (ASYS Hitech $\mathrm{GmbH}$ ). The cell viability was described as survival rate (\%) compared with the mean absorbency of the control. The cell viability (\%) in each determination was calculated using the following equation [31]: 100

Changes of cell numbers $(\%)=\left[\left(\mathrm{A}_{\text {sample }}-\mathrm{A}_{\text {blank }}\right) /\left(\mathrm{A}_{\text {control }}-\mathrm{A}_{\text {blank }}\right)\right] \times$

\section{Measurement of cytokine concentrations using ELISA}

Th1 (IL-2, IFN- $\gamma$ ) and Th2 (IL-4, IL-5, IL-10) cytokine secretion levels were measured using a sandwich ELISA according to the manufacturer's cytokine ELISA protocol (mouse DuoSet ELISA Development system, R\&D Systems, Minneapolis, MN). Briefly, aliquots of $100 \mu \mathrm{l}$ of anti-mouse IL-2 (Duo Set ELISA Development 
Kits DY402), IFN- $\gamma$ (cat. no., DY485), IL-4 (cat. no., DY404), IL-5 (cat. no., DY405) or IL-10 (cat. no., DY417) captured antibodies (diluted 1:180 with PBS) were respectively added to 96-microwell plate wells and incubated at $4^{\circ} \mathrm{C}$ overnight. The plates were washed 3 times with an ELISA wash buffer (0.05\% Tween-20 in PBS, pH 7.4) to remove unbound antibodies. Aliquots of $200 \mu$ l blocking buffer [ $1 \%$ bovine serum albumin (BSA; A9418; Sigma-Aldrich; Merck KGaA] and 0.05\% NaN3 (Sigma-Aldrich Co., S2002, St. Louis, MO) in PBS) were added to each well at $25^{\circ} \mathrm{C}$ for $1 \mathrm{~h}$ to block non-specific binding. The plates were washed 3 times with the ELISA wash buffer. Aliquots of $100 \mu$ test sample (the supernatant of splenocyte culture obtained by centrifuging at $25^{\circ} \mathrm{C}, 400 \times \mathrm{g}$ for $10 \mathrm{~min}$ ) or standard in reagent diluent [0.1\% BSA (A9418; Sigma-Aldrich; Merck KGaA) in PBS] were added to the 96-microwell plate wells at $25^{\circ} \mathrm{C}$ for $2 \mathrm{~h}$. A 7 point (in duplicate) standard curve using 2-fold serial dilutions in reagent diluent were performed. The plates were washed 3 times with an ELISA wash buffer. Aliquots of $100 \mu$ l of anti-mouse IL-2, IFN- $\gamma$, IL-4, IL- 5 or IL- 10 detection antibody (biotinylated goat anti-mouse monoclonal antibody at 1:180 dilution in reagent diluent) were respectively added to each well at $25^{\circ} \mathrm{C}$ for $2 \mathrm{~h}$. The plates were washed 3 times with the ELISA wash buffer. Aliquots of $100 \mu \mathrm{l}$ working streptavidin-horseradish peroxidase dilution were added to each well and the plate was incubated at $25^{\circ} \mathrm{C}$ for $20 \mathrm{~min}$. The plates were washed with ELISA wash buffer 3 times. Aliquots of $100 \mu$ substrate solution (tetramethylbenzidine) was pipetted into the 96-microwell plate wells. The plate was incubated at $25^{\circ} \mathrm{C}$ for $20 \mathrm{~min}$ to allow the color to develop. Aliquots of $50 \mu \mathrm{l}$ stop solution $\left(2 \mathrm{~N} \mathrm{H}_{2} \mathrm{SO}_{4}\right)$ were added to each well to stop the reaction. The plate was measured for absorbance at $450 \mathrm{~nm}$ on an ELISA plate reader (ASYS Hitech $\mathrm{GmbH}$ ). The cytokine concentrations were determined using 7 point standard curves. The sensitivity of the ELISA kits used in the present study was $<15.6 \mathrm{pg} / \mathrm{ml}[31]$.

\section{Statistical analysis}

Results are presented as the mean \pm standard deviation. Differences between means were analysed using one-way analysis of variance, followed by Duncan's multiple range test using SPSS 19.0 (IBM SPSS, Armonk, NY). The associations between cytokine levels in the SCM and the viabilities of MCF-7 cells were described using the Pearson product-moment correlation coefficient $(r) . \mathrm{P}<0.05$ was considered to indicate a statistically significant difference.

\section{Results}

\section{UV-Vis absorption spectrum analyses of five isolated polysaccharide fractions}

To characterize the isolated polysaccharide fractions, the UV-Vis absorption spectra of GSPS, CBPS, BBPS, RFLPS and YFLPS were recorded (Figure 1). The results exhibited that the maximal absorption peak of GSPS distributed at $210 \mathrm{~nm}$ while a minor peak existed at the $270 \mathrm{~nm}$ (range from 260 to $280 \mathrm{~nm}$ ) (Figure 1A). Interestingly, CBPS, BBPS, RFLPS and YFLPS have similar UV-Vis absorption spectra. The maximal CPBS and BBPS absorption peaks were distributed at $230 \mathrm{~nm}$ while a minor peak existed at $270 \mathrm{~nm}$ (Figures $1 \mathrm{~B}$ and $1 \mathrm{C}$ ). The maximal RFLPS and YFLPS absorption peaks were distributed at $220 \mathrm{~nm}$ with a shoulder around 260 280 nm (Figures 1D and 1E). All of the isolated polysaccharide fractions exhibited their maximal absorption peaks around $210 \sim 230 \mathrm{~nm}$, suggesting that these particular polysaccharides may have an absorption peak around 210 $230 \mathrm{~nm}$ (Figure 1). Therefore, an absorbance at $220 \mathrm{~nm}$ was suggested for an indicator of these polysaccharides in the following purification experiment. All of the isolated polysaccharide fractions presented a minor peak around
260 280 nm (Figure 1), implying that proteinaceous components having absorption at $280 \mathrm{~nm}$ existed in the five isolated polysaccharide fractions. Our results further suggest that all five selected polysaccharide fractions might be glycoproteins or proteopolysaccharides. GSPS absorbance at $270 \mathrm{~nm}$ (range from 260 to $280 \mathrm{~nm}$ ) was much lower than those of the other four isolated polysaccharide fractions, indicating the lowest protein constituent content in GSPS among the five isolated polysaccharide fractions (Figure 1).

\section{Yields as well as ratio estimates of total carbohydrate and protein contents in the five isolated polysaccharide fractions}

Yields as well as ratio estimates of total carbohydrate and protein contents in GSPS, CBPS, BBPS, RFLPS and YFLPS were measured to further characterize the isolated polysaccharides. The results showed that the yields of isolated GSPS, CBPS, BBPS, RFLPS and YFLPS from air-dried powders of guava seed, common buckwheat, bitter buckwheat, red Formosa lambsquarters and yellow Formosa lambsquarters were $1.39 \pm 0.20,3.11 \pm 0.03,2.64 \pm 0.08,3.76 \pm 0.42$ and $3.03 \pm 0.05 \%$ $(\mathrm{w} / \mathrm{w})$, respectively (Table 1$)$. The total protein and carbohydrate constituent ratios in GSPS, CBPS, BBPS, RFLPS and YFLPS were $60.7 \%$ vs. $39.3 \%, 15.5 \%$ vs. $84.5 \%, 14.4 \%$ vs. $85.6 \%, 42.0 \%$ vs. $58.0 \%$, and $31.1 \%$ vs. $68.9 \%(\mathrm{w} / \mathrm{w})$, respectively, suggesting that these five isolated polysaccharide fractions are proteopolysaccharides or glycoproteins (Table 1). Among five selected polysaccharide fractions, GSPS had the highest sugar constituent content $(60.7 \%)$ while BBPS had the highest protein constituent content (85.6\%).

\section{Molecular weights of five selected polysaccharide fractions}

The isolated polysaccharide fractions were purified and characterized using Sepharose 6B gel filtration. The chromatograms of five selected polysaccharide fractions using the gel filtration column detected by absorbance at $280 \mathrm{~nm}$ (for protein determination) and $220 \mathrm{~nm}$ (for polysaccharide determination) are shown in Figure 2. Importantly, purified fractions from five selected polysaccharides were abundant in both protein $(280 \mathrm{~nm})$ and polysaccharide $(220$ $\mathrm{nm}$ ) fractions, further suggesting that these purified fractions are proteopolysaccharides or glycoproteins. The chromatographic profiles are identical to analyses of total carbohydrate and protein contents in the five isolated polysaccharide fractions (Table 1). Furthermore, blue dextran (MW: 2,000 kDa) and protein standards (MW: 66,000-670,000 $\mathrm{Da})$ were selected to calibrate molecular weights of each identified polysaccharides fraction (Figure $2 \mathrm{~A}$ ).

The results showed that GSPS further resolved into three different peaks, fraction-1 (F1), fraction-2 (F2) and fraction-3 (F3), suggesting that GSPS is comprised of three different proteopolysaccharides or glycoproteins, coded as GSF1, GSF2 and GSF3 (Figure 2B). The molecular weights of GSF1, GSF2 and GSF3 estimated at $6.1 \times 10^{8} \mathrm{Da}$, $3.3 \times 10^{7} \mathrm{Da}$ and $6.8 \times 10^{3} \mathrm{Da}$, respectively.

CBPS and BBPS have similar absorption spectra (Figures $2 \mathrm{C}$ and 2D). CBPS and BBPS further resolved into three different peaks, suggesting that CBPS and BBPS are comprised of three different polysaccharide fractions, coded as $\mathrm{CBF} 1, \mathrm{CBF} 2$ and $\mathrm{CBF} 3$, or $\mathrm{BBF} 1$, $\mathrm{BBF} 2$ and $\mathrm{BBF} 3$ (Figures 2C and 2D). The molecular weights of $\mathrm{CBF} 1$, $\mathrm{CBF} 2$ and CBF3 estimated at $4.5 \times 10^{7} \mathrm{Da}, 1.8 \times 10^{5} \mathrm{Da}$ and $9.4 \times 10^{3} \mathrm{Da}$, respectively. The molecular weights of $\mathrm{BBF} 1, \mathrm{BBF} 2$ and $\mathrm{BBF} 3$ estimated at $4.5 \times 10^{7} \mathrm{Da}, 2.5 \times 10^{5} \mathrm{Da}$ and $1.3 \times 10^{3} \mathrm{Da}$, respectively.

Interestingly, RFLPS and YFLPS also have similar absorption spectra (Figures 2E and 2F). The results showed that RFLPS and YFLPS further resolved into two different peaks, coded as RFLF1and RFLF2, or YFLF1 
Citation: Lin HC, Lin JY (2017) Splenocyte-Conditioned Media Inhibit Breast Cancer MCF-7 Cell Growth, Associated with Increased Th2/Th1 Cytokine Secretion Ratio in the Media using Five Selected Polysaccharides. J Immuno Biol 2: 121.doi: 10.4172/2476-1966.1000121

(A)

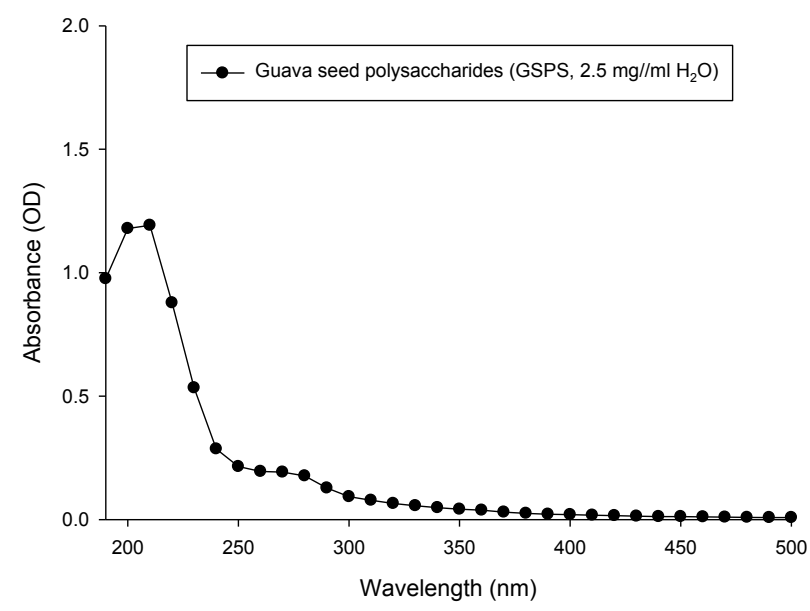

(C)

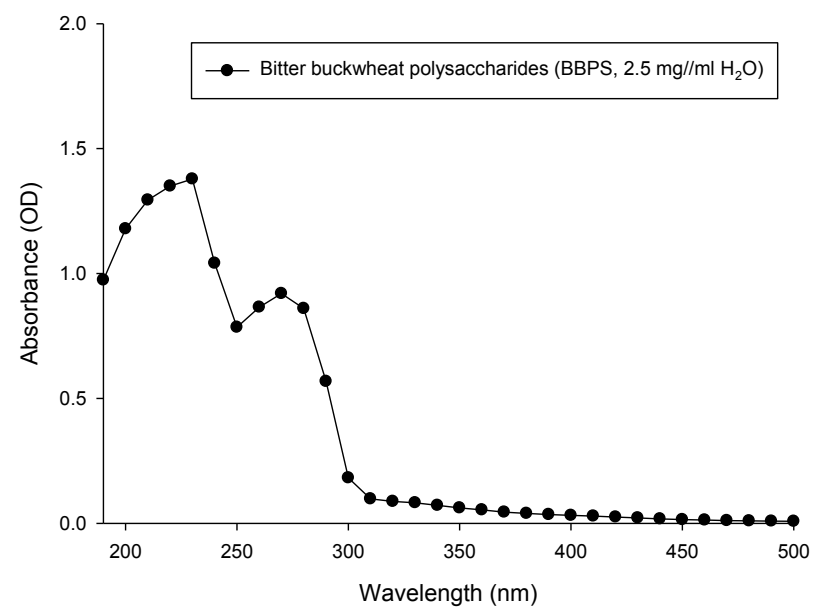

(E)

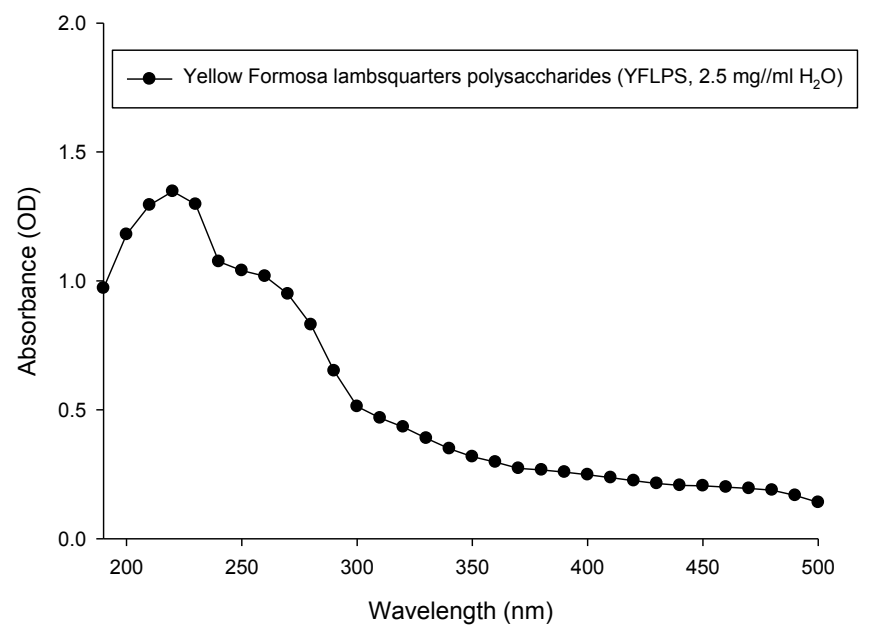

(B)

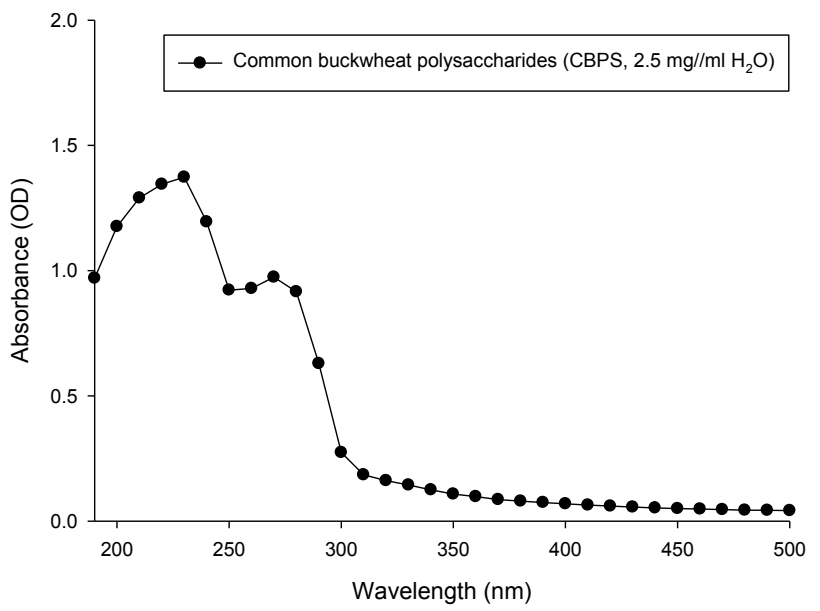

(D)

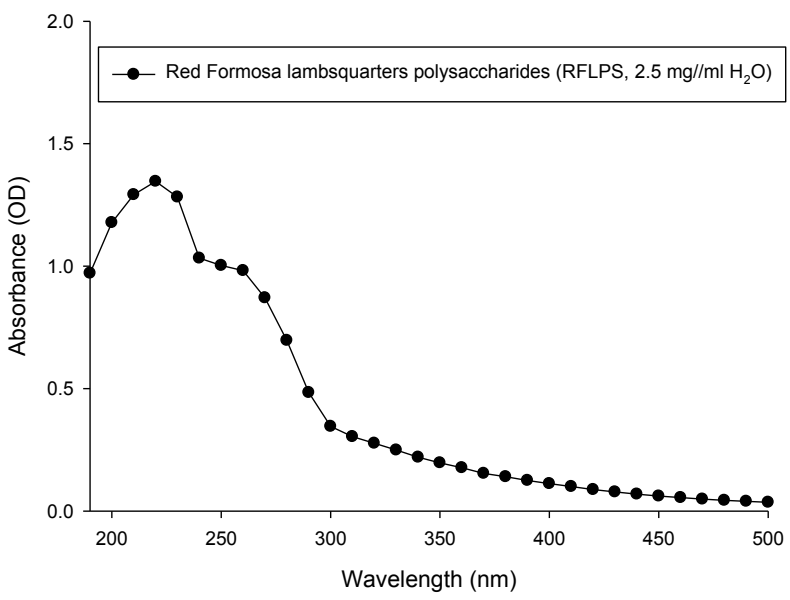

Figure 1: UV-Vis absorption spectra of polysaccharides isolated from (A) guava seed (GSPS), (B) common buckwheat (CBPS), (C) bitter buckwheat (BBPS), (D) red Formosa lambsquarters (RFLPS) and (E) yellow Formosa lambsquarters (YFLPS). 
(A)
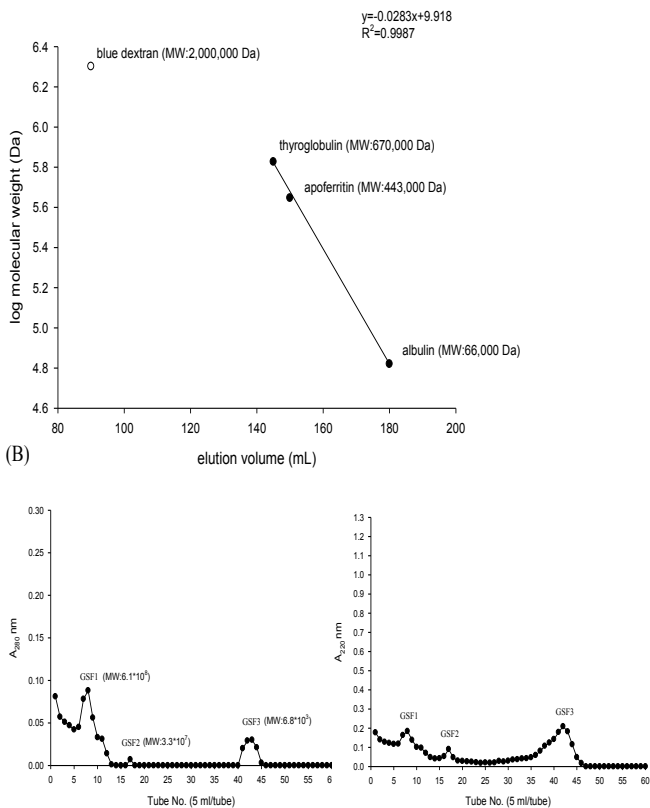

(C)
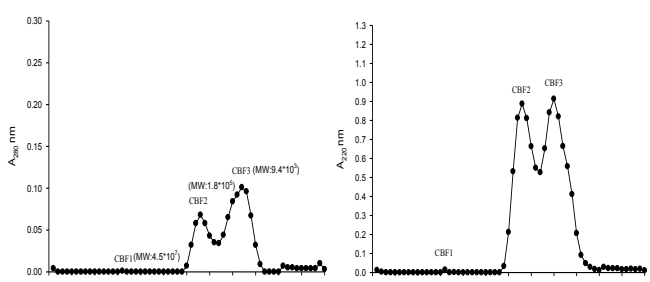

(D)
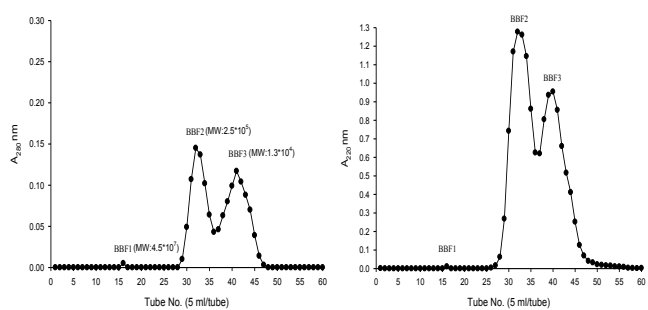

(E)
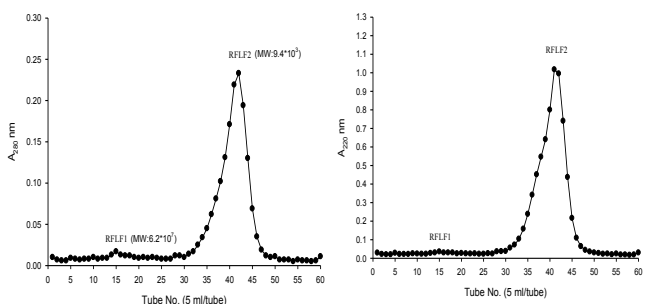

(F)
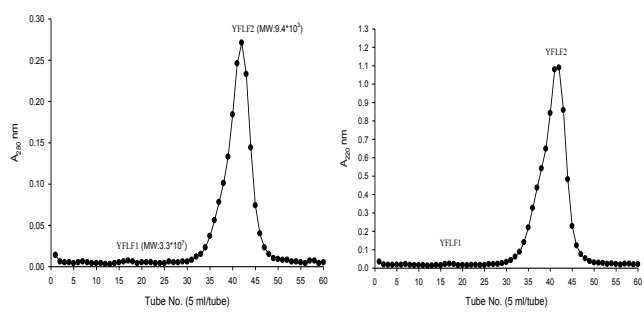

Figure 2: A calibration curve obtained from (A) protein standards and compared to blue dextran, as well as chromatographic profiles of polysaccharides isolated from (B) guava seed (GSPS), (C) common buckwheat (CBPS), (D) bitter buckwheat (BBPS), (E) red Formosa lambsquarters (RFLPS) and (F) yellow Formosa lambsquarters (YFLPS) using Sepharose 6B gel filtration detected by the absorbance at $280 \mathrm{~nm}$ and $220 \mathrm{~nm}$. The column $(2.5 \mathrm{~cm} \times 47 \mathrm{~cm})$ was eluted at a flow rate of $1.25 \mathrm{ml} / \mathrm{min}$ with $0.15 \mathrm{M} \mathrm{NaCl}$.

\begin{tabular}{|c|c|c|c|}
\hline \multirow{2}{*}{$\begin{array}{c}\text { Isolated } \\
\text { polysaccha-rides }\end{array}$} & Yields (\%, w/w) & \multicolumn{2}{|c|}{$\begin{array}{c}\text { Estimates of sugar/protein } \\
\text { constituent content ratios in the } \\
\text { isolated polysaccharides }\end{array}$} \\
\cline { 3 - 4 } & Sugar (\%) & Protein (\%) \\
\hline GSPS & $1.39 \pm 0.20$ & 60.7 & 39.3 \\
\hline CBPS & $3.11 \pm 0.03$ & 15.5 & 84.5 \\
\hline BBPS & $2.64 \pm 0.08$ & 14.4 & 85.6 \\
\hline RFLPS & $3.76 \pm 0.42$ & 42.0 & 58.0 \\
\hline YFLPS & $3.03 \pm 0.05$ & 31.1 & 68.9 \\
\hline
\end{tabular}

Table 1: Yields as well as ratio estimates of total carbohydrate and protein contents in five isolated polysaccharide fractions. Values are means $\pm \operatorname{SD}(n=3$ replications).

and YFLF2 (Figures 2E and 2F). The molecular weights of RFLF1 and RFLF2 estimated at $6.2 \times 10^{7} \mathrm{Da}$ and $9.4 \times 10^{3} \mathrm{Da}$, respectively. The molecular weights of YFLF1 and YFLF2 estimated at $3.3 \times 10^{7} \mathrm{Da}$ and $9.4 \times 10^{3} \mathrm{Da}$, respectively.

\section{Optimal concentrations of 5 selected crude polysaccharides administrations to mouse primary splenocytes}

Cell viabilities of mouse primary splenocytes treated with different concentrations of the selected polysaccharides were assayed to determine the non-cytotoxic optimal concentrations of the polysaccharides. The results demonstrated that GSPS, CBPS, BBPS, RFLPS and YFLPS administrations, at the indicated concentrations of $1.6,8,40,200,500$ and $1,000 \mu \mathrm{g} / \mathrm{ml}$, respectively, did not significantly inhibit splenocyte cell viability compared with the control $(\mathrm{P}>0.05$; Figure 3$)$.

In contrast, $1.6-500 \mu \mathrm{g} / \mathrm{ml}$ CBPS and BBPS treatment significantly increased the cell viabilities of splenocytes compared with the control $(\mathrm{P}<0.05$; Figures $3 \mathrm{~A}-\mathrm{E})$, suggesting that CBPS and BBPS may stimulate immune cells to proliferate. To avoid any unpredictable cytotoxicity at the higher concentrations, 1.6, 8, 40 and $200 \mu \mathrm{g} / \mathrm{ml}$ GSPS, CBPS, BBPS, RFLPS and YFLPS were used as optimal concentrations to treat the cells in the following cytokine secretion assays and SCM preparation.

\section{Effects of crude polysaccharide treatments on Th1/Th2 cytokine secretions by primary splenocytes}

The results demonstrated that the level of IL-2 secreted by the primary splenocytes were significantly reduced by $200 \mu \mathrm{g} / \mathrm{ml}$ GSPS compared with the control $(\mathrm{P}<0.05$; Table 2$)$. In addition, IL-10 levels secreted by the primary splenocytes were significantly increased by 200 $\mu \mathrm{g} / \mathrm{ml}$ GSPS, BBPS, RFLPS and YFLPS treatment compared with the control $(\mathrm{P}<0.05$; Table 2), while CBPS treatment at $200 \mu \mathrm{g} / \mathrm{ml} \mathrm{did} \mathrm{not}$ significantly affect IL-10 secretion compared with the control $(\mathrm{P}>0.05$; Table 2). However, the majority of the Th1 (IFN- $\gamma$ ) and Th2 (IL-4 and IL-5) levels secreted by polysaccharide administered-splenocytes were 
Citation: Lin HC, Lin JY (2017) Splenocyte-Conditioned Media Inhibit Breast Cancer MCF-7 Cell Growth, Associated with Increased Th2/Th1 Cytokine Secretion Ratio in the Media using Five Selected Polysaccharides. J Immuno Biol 2: 121.doi: 10.4172/2476-1966.1000121

A

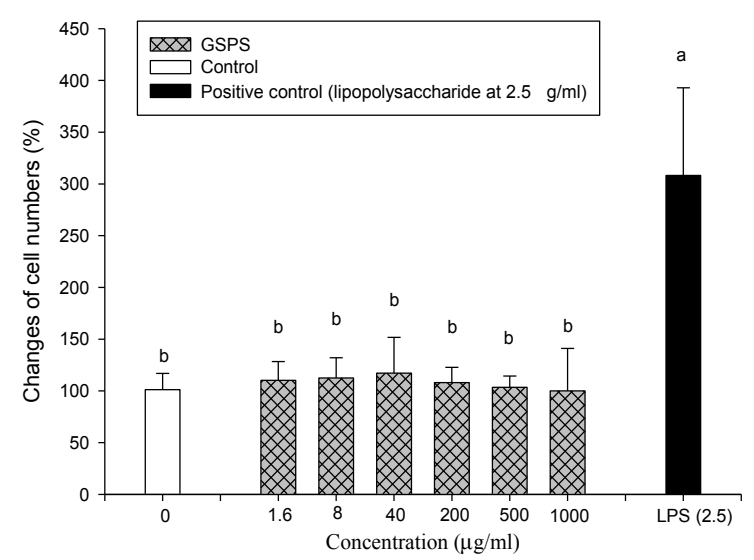

$\mathrm{C}$

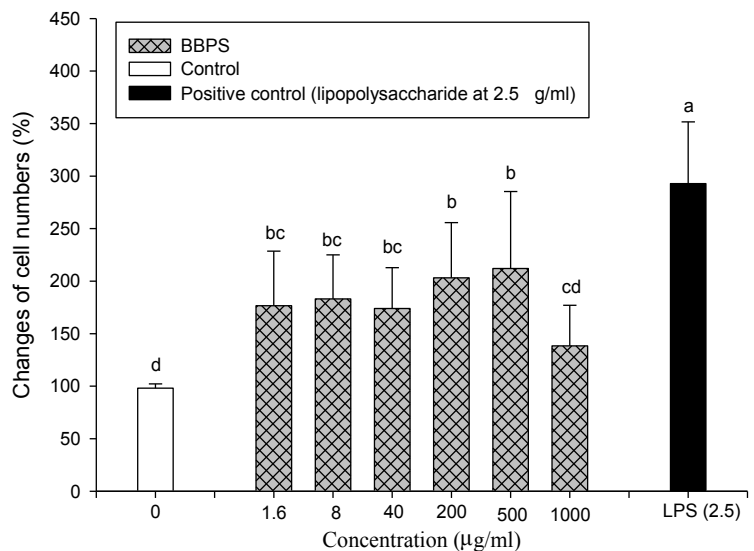

$\mathrm{B}$

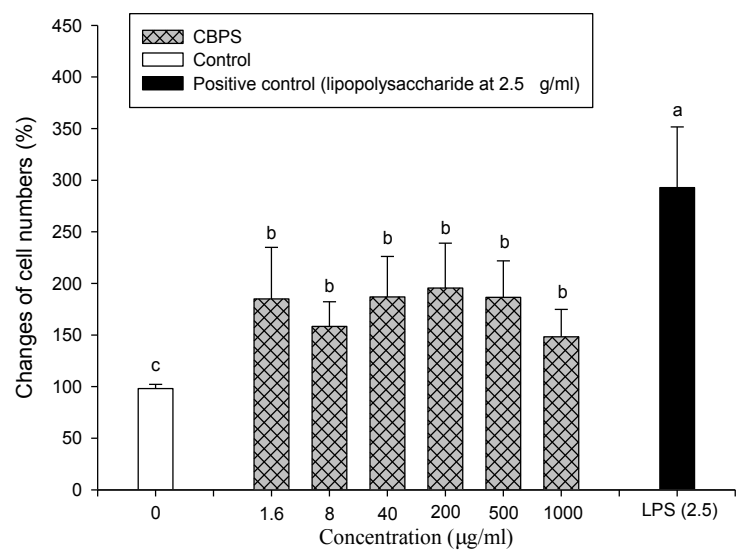

$\mathrm{D}$

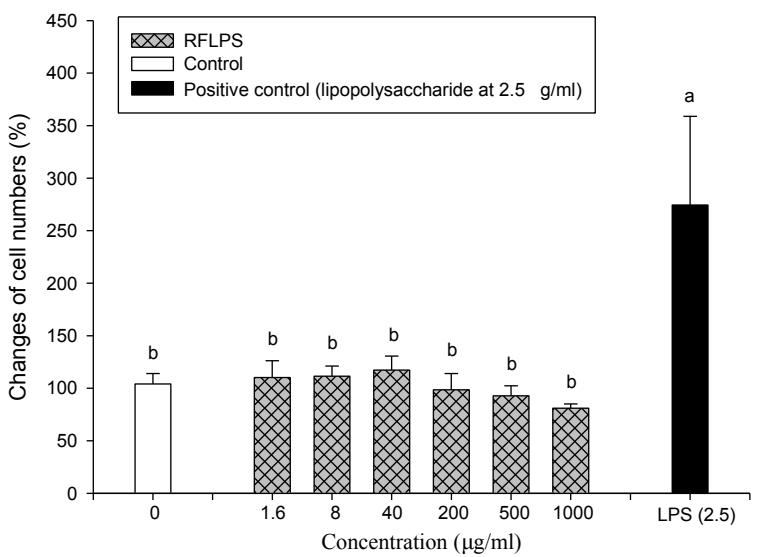

$\mathrm{E}$

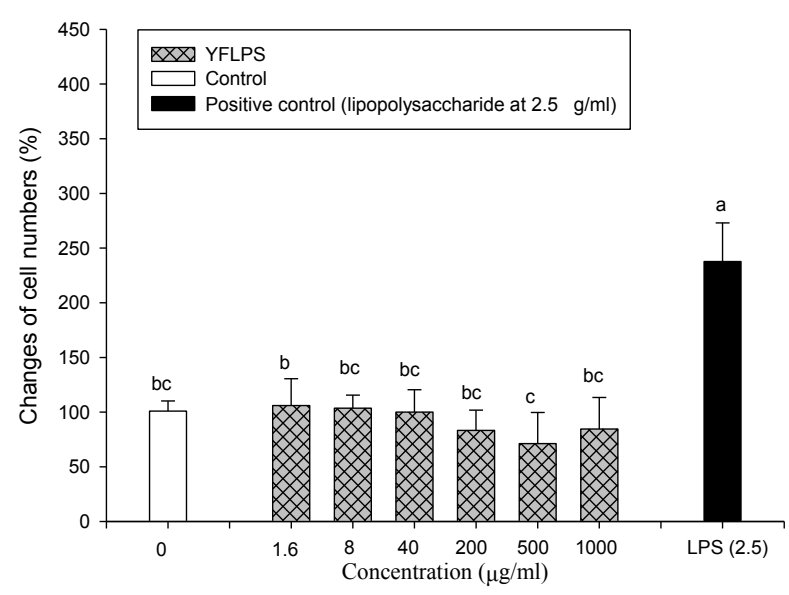

Figure 3: Effect of treatment with (A) GSPS, (B) CBPS, (C) BBPS, (D) RFLPS and (E) YFLPS on the cell viability of splenocytes from female BALB/c mice. Values are presented as the mean \pm standard deviation $(n=6)$. Bars not sharing a common small letter are significantly different $(P<0.05)$. Each cell population $\left(5 \times 10^{6}\right.$ cells $\left./ \mathrm{ml}\right)$ was treated with the polysaccharides at the indicated concentrations for $72 \mathrm{~h}$. Cell viability was determined using an MTT assay and calculated using the equation: Changes

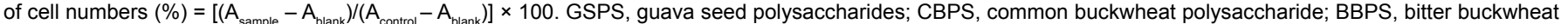
polysaccharide; RFLPS, red formosa lambsquarters polysaccharide; YFLPS, yellow formosa lambsquarters polysaccharide; LPS, lipopolysaccharide. 
Citation: Lin HC, Lin JY (2017) Splenocyte-Conditioned Media Inhibit Breast Cancer MCF-7 Cell Growth, Associated with Increased Th2/Th1 Cytokine Secretion Ratio in the Media using Five Selected Polysaccharides. J Immuno Biol 2: 121.doi: 10.4172/2476-1966.1000121

Page 8 of 14

\begin{tabular}{|c|c|c|c|c|c|c|}
\hline Cytokine (pg/ml) & conc $(\mu \mathrm{g} / \mathrm{ml})$ & GSPS & CBPS & BBPS & RFLPS & YFLPS \\
\hline \multirow{6}{*}{ IL-2 } & 0 & $8.5 \pm 6.1^{\mathrm{CD}}$ & $8.5 \pm 6.1^{\mathrm{B}}$ & $8.5 \pm 6.1^{\mathrm{B}}$ & $8.5 \pm 6.1^{\mathrm{B}}$ & $8.5 \pm 6.1^{c}$ \\
\hline & 1.6 & $15.2 \pm 3.8^{B}$ & $21.2 \pm 2.2^{\mathrm{A}}$ & $22.5 \pm 9.3^{A}$ & $20.1 \pm 2.8^{A}$ & $17.3 \pm 6.6^{\mathrm{B}}$ \\
\hline & 8 & $14.2 \pm 5.9^{B}$ & $21.7 \pm 6.9^{A}$ & $21.0 \pm 9.6^{A}$ & $20.2 \pm 12.1^{\mathrm{A}}$ & $16.5 \pm 5.5^{\mathrm{B}}$ \\
\hline & 40 & $11.3 \pm 6.5^{\mathrm{BC}}$ & $23.3 \pm 6.7^{A}$ & $20.9 \pm 5.3^{A}$ & $21.6 \pm 6.0^{A}$ & $15.3 \pm 6.4^{B}$ \\
\hline & 200 & $3.6 \pm 2.9^{D}$ & $28.4 \pm 8.1^{\mathrm{A}}$ & $28.2 \pm 5.3^{A}$ & $16.0 \pm 6.0^{\mathrm{AB}}$ & $16.3 \pm 7.5^{\mathrm{B}}$ \\
\hline & LPS & $24.4 \pm 4.6^{\mathrm{A}}$ & $24.4 \pm 4.6^{A}$ & $24.4 \pm 4.6^{A}$ & $24.4 \pm 4.6^{A}$ & $24.4 \pm 4.6^{\mathrm{A}}$ \\
\hline \multirow{6}{*}{ IFN-y } & 0 & ND & ND & ND & ND & ND \\
\hline & 1.6 & ND & ND & ND & ND & ND \\
\hline & 8 & ND & ND & ND & ND & ND \\
\hline & 40 & ND & ND & ND & ND & ND \\
\hline & 200 & $6.0 \pm 5.7$ & ND & ND & ND & ND \\
\hline & LPS & ND & ND & ND & ND & ND \\
\hline \multirow{6}{*}{ IL-4 } & 0 & ND & ND & ND & ND & ND \\
\hline & 1.6 & ND & ND & ND & ND & ND \\
\hline & 8 & ND & ND & ND & ND & ND \\
\hline & 40 & ND & ND & ND & ND & ND \\
\hline & 200 & ND & ND & ND & ND & ND \\
\hline & LPS & $8.3 \pm 8.2$ & $8.3 \pm 8.2$ & $8.3 \pm 8.2$ & $8.3 \pm 8.2$ & $8.3 \pm 8.2$ \\
\hline \multirow{6}{*}{ IL-5 } & 0 & ND & ND & ND & ND & ND \\
\hline & 1.6 & ND & ND & ND & ND & ND \\
\hline & 8 & ND & ND & ND & ND & ND \\
\hline & 40 & ND & ND & ND & ND & ND \\
\hline & 200 & ND & ND & ND & ND & ND \\
\hline & LPS & ND & ND & ND & ND & ND \\
\hline \multirow{6}{*}{ IL-10 } & 0 & ND & ND & ND & ND & ND \\
\hline & 1.6 & $20.9 \pm 14.3^{\mathrm{CD}}$ & $13.7 \pm 9.8^{\mathrm{B}}$ & $11.6 \pm 8.6^{c}$ & $8.8 \pm 6.3^{c}$ & ND \\
\hline & 8 & $38.4 \pm 14.9^{\mathrm{CD}}$ & $14.8 \pm 8.5^{\mathrm{B}}$ & $25.9 \pm 14.2^{\mathrm{C}}$ & $11.5 \pm 4.9^{c}$ & ND \\
\hline & 40 & $69.8 \pm 30.3^{\mathrm{BC}}$ & $21.3 \pm 10.7^{\mathrm{B}}$ & $76.3 \pm 42.2^{c}$ & $52.6 \pm 10.3^{c}$ & $17.0 \pm 15.7^{c}$ \\
\hline & 200 & $111.6 \pm 30.1^{\mathrm{B}}$ & $23.9 \pm 4.0^{\mathrm{B}}$ & $257.2 \pm 104.8^{8}$ & $178.9 \pm 66.8^{\mathrm{B}}$ & $121.1 \pm 50.2^{\mathrm{B}}$ \\
\hline & LPS & $637.8 \pm 128.6^{A}$ & $637.8 \pm 128.6^{A}$ & $637.8 \pm 128.6^{A}$ & $637.8 \pm 128.6^{A}$ & $637.8 \pm 128.6^{A}$ \\
\hline
\end{tabular}

The limit of cytokine ELISA detection kits used in the present study was $<15.6 \mathrm{pg} / \mathrm{ml}$. Each cell population $\left(5 \times 10^{6} \mathrm{cells} / \mathrm{ml}\right.$ medium $)$ was treated with the polysaccharides at the indicated concentrations for $48 \mathrm{~h}$. Values within same column in the same cytokine item not sharing a common capital superscript letter are significantly different $(\mathrm{P}<0.05)$, as determined by one-way analysis of variance, followed by Duncan's multiple range test. Values are presented as the mean \pm standard deviation ( $n=8)$. Lipopolysaccharide $(2.5 \mu \mathrm{g} /$ $\mathrm{ml}$ ) was selected as a positive control. GSPS, guava seed polysaccharides; CBPS, common buckwheat polysaccharides; BBPS, bitter buckwheat polysaccharides; RFLPS, red Formosa lambsquarters polysaccharides; YFLPS, yellow Formosa lambsquarters polysaccharides; Th, helper T-cell; IL, interleukin; IFN, interferon; ND, not detectable.

Table 2: Effect of 5 different polysaccharide treatments on Th1/Th2 cytokine secretions using splenocytes from female BALB/c mice in vitro.

lower than the sensitivity of the ELISA kit used in the present study (Table 2). The western blotting analysis and RT-PCR are suggested to use to measure the proteins changing, especial for glycoproteins, in the future. Additional analysis of the Th1/Th2 cytokine secretion ratios by the splenocytes treated with the 5 different polysaccharides indicated that the IL-10/IL-2 (Th2/ Th1) secretion ratios were significantly increased by GSPS, BBPS, RFLPS and YFLPS treatment at the indicated concentration of $200 \mu \mathrm{g} / \mathrm{ml}(\mathrm{P}<0.05$; Figure 4), but CBPS treatment at $200 \mu \mathrm{g} / \mathrm{ml}$ did not significantly affect IL$10 / \mathrm{IL}-2$ secretion ratios compared to the control ( $\mathrm{P}>0.05$; Figures $4 \mathrm{~A}-\mathrm{E})$.
The present results suggested that treatment with the 5 selected polysaccharides, in particular $200 \mu \mathrm{g} / \mathrm{ml}$ GSPS, BBPS and RFLPS, significantly enhanced the Th2 immune response in the splenocyte cultures.

Direct action of treatment with the 5 polysaccharides on MCF-7 cell viability

To evaluate whether polysaccharides inhibited the growth of 
A

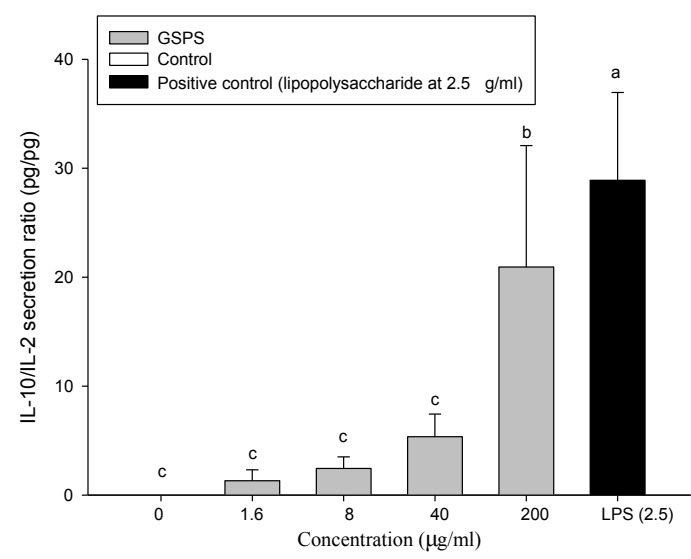

$\mathrm{C}$

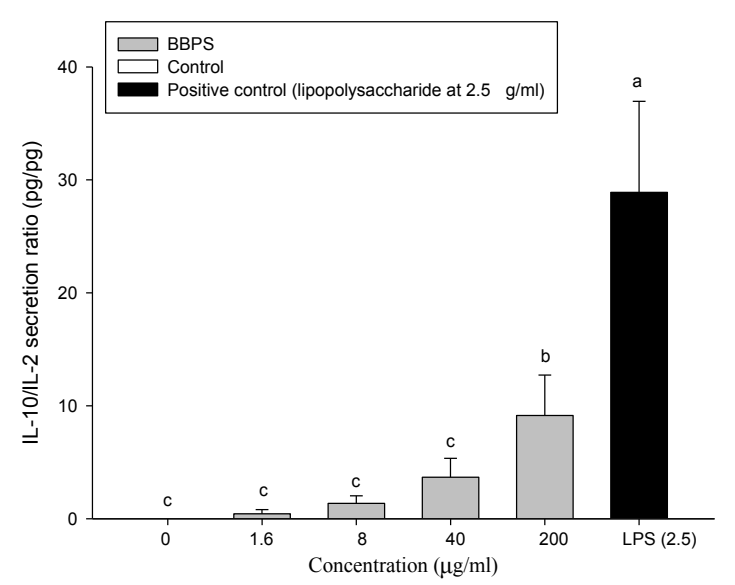

B

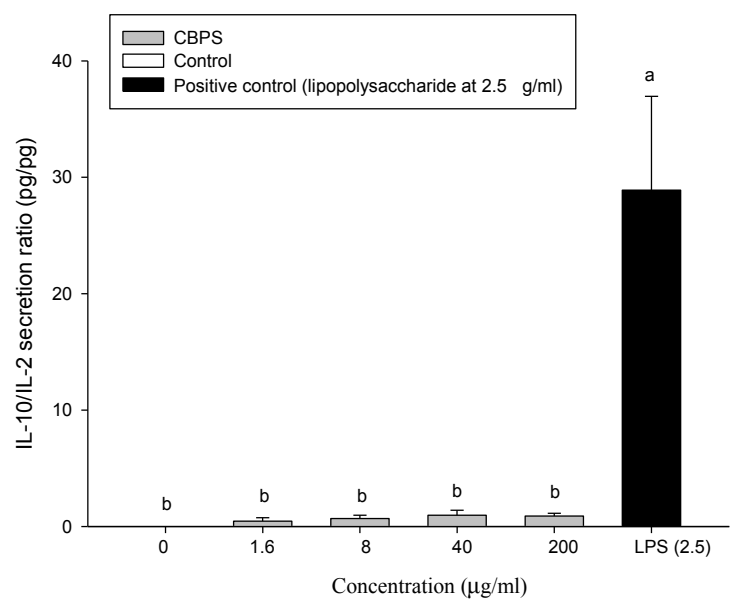

$\mathrm{D}$

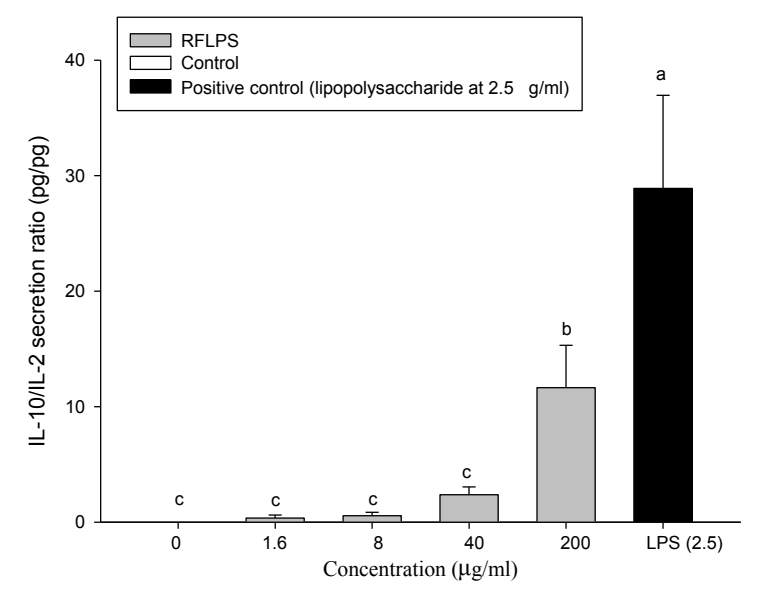

$\mathrm{E}$

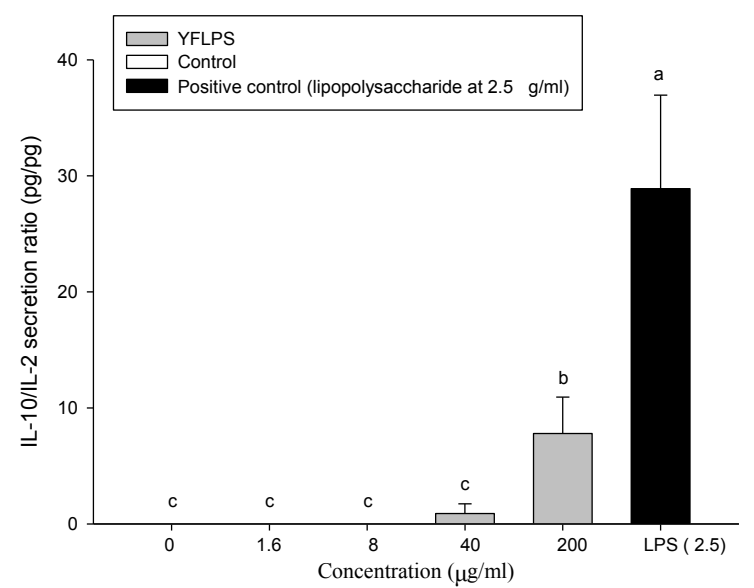

Figure 4: Effect of (A) GSPS, (B) CBPS, (C) BBPS, (D) RFLPS and (E) YFLPS administration on the IL-10/IL-2 (Th2/Th1) cytokine secretion ratio by splenocytes from female BALB/c mice. Values are presented as the mean \pm standard deviation $(n=8)$. Bars not sharing a common small letter are significantly different $(P<0.05)$. Each cell population $\left(5 \times 10^{6} \mathrm{cells} / \mathrm{ml}\right.$ medium) was treated with the polysaccharides at the indicated concentrations of $0,1.6,8,40$ and $200 \mu \mathrm{g} / \mathrm{ml}$ for $48 \mathrm{~h}$. GSPS, guava seed polysaccharides; CBPS, common buckwheat polysaccharides; BBPS, bitter buckwheat polysaccharides; RFLPS, red formosa lambsquarters polysaccharides; YFLPS, yellow formosa lambsquarters polysaccharides; IL, interleukin; Th, helper T-cell; LPS, lipopolysaccharide. 
MCF-7 cells through direct action, the 5 selected polysaccharides at the indicated concentrations of $1.6,8,40$ and $200 \mu \mathrm{g} / \mathrm{ml}$ were added to MCF-7 cell cultures. Paclitaxel administration at $2.5 \mu \mathrm{M}$ was selected as a positive control. MCF-7 cell viability was determined using an MTT assay. The results demonstrated that paclitaxel significantly inhibited the growth of MCF-7 cells either through incubation for 24 or $48 \mathrm{~h}$ compared with the negative control $(\mathrm{P}<0.05$; Figure 5$)$.

However, administration of the 5 selected polysaccharides, GSPS, CBPS, BBPS, RFLPS and YFLPS at the indicated concentrations did not significantly inhibit the growth of MCF-7 cells compared with the control $(\mathrm{P}>0.05$; Figures $5 \mathrm{~A}-\mathrm{E})$, suggesting that there is no direct action by the 5 selected polysaccharides on MCF-7 cell viability.

\section{Effects of SCM administration on the growth of MCF-7 cells}

To evaluate whether polysaccharides inhibited the growth of MCF7 cells via tumor immunotherapy, SCM prepared using the 5 selected polysaccharides at the indicated concentrations of $0,1.6,8,40$ and 200 $\mu \mathrm{g} / \mathrm{ml}$ were collected to treat MCF-7 cells. Paclitaxel administration at $2.5 \mu \mathrm{M}$ was selected as a positive control in the experiments. No significant differences were identified in the viabilities of MCF-7 cells between those cultured with MEM/EBSS and TCM medium, suggesting that the medium for splenocytes culture (TCM medium) in the SCM did not significantly affect MCF-7 cell growth (Figure 6). Paclitaxel (treatment control) significantly inhibited MCF-7 cell growth compared with the negative control (cells alone in MEM/ EBSS medium or TCM medium) through incubation for 24 or $48 \mathrm{~h}$ $(\mathrm{P}<0.05$; Figure 6). Notably, the positive control group (SCM without polysaccharide treatment) significantly inhibited MCF-7 cell viability compared with the negative control (cells alone in MEM/EBSS medium or TCM medium) incubated for 24 or $48 \mathrm{~h}(\mathrm{P}<0.05$; Figures $6 \mathrm{~A}-\mathrm{E})$, suggesting that the secretion of cytokines by splenocytes may inhibit MCF-7 cell viability. SCM with polysaccharide treatment significantly inhibited MCF-7 cell viability compared with the negative control $(\mathrm{P}<0.05$; Figure 6$)$. However, SCM with polysaccharide treatment did not significantly inhibit MCF-7 cell viability compared with the positive control ( $\mathrm{P}>0.05$; Figure 6$)$. At the higher concentrations, GSPS-, BBPSand RFLPS-treated SCM had slightly increased inhibitory effects against MCF-7 cell growth compared with non-treated SCM (Figure 6). As SCM treatments significantly inhibited MCF-7 cell viability through incubation for 24 or $48 \mathrm{~h}(\mathrm{P}<0.05$; Figure 6$)$, it was hypothesized that cytokine secretion by splenocytes may inhibit MCF-7 cell viability.

\section{The association between cytokine secretion levels in the SCM and the viability of MCF-7 cells}

To clarify the association between cytokine levels and cancer cell viability, correlations between cytokine secretion levels secreted by splenocytes in the SCM and the survival rate of MCF-7 cells treated with the corresponding SCM (administered with 5 selected polysaccharides at the indicated concentrations of $0,8,40$, and $200 \mu \mathrm{g} / \mathrm{ml}$, respectively) were determined using Pearson's correlation coefficients (r; Figure 7). No significant positive correlation was observed between IL-2 (a Th1 cytokine) secretion levels in the SCM and the survival rate of MCF7 cells treated with the corresponding SCM for $24(\mathrm{r}=0.113, \mathrm{P}=0.272$; Figure $7 \mathrm{~A})$ or $48 \mathrm{~h}(\mathrm{r}=0.157, \mathrm{P}=0.126$; Figure $7 \mathrm{~B})$. Notably, there was a significant negative correlation between IL-10 (a Th2 cytokine) secretion levels in the SCM and the survival rate of MCF-7 cells treated with the corresponding SCM for $24(\mathrm{r}=-0.344, \mathrm{P}=0.001$; Figure $7 \mathrm{C})$ or $48 \mathrm{~h}(\mathrm{r}=-0.352, \mathrm{P}<0.001$; Figure $7 \mathrm{D})$. Additional analysis on the correlation between Th2/Th1 secretion ratios and MCF-7 cell growth demonstrated a significant negative correlation between the IL-10/IL-2
(Th2/Th1) cytokine secretion ratio and the survival rate of MCF-7 cells treated with the corresponding SCM for $24(\mathrm{r}=-0.224, \mathrm{P}=0.028$; Fig. $7 \mathrm{E})$ or $48 \mathrm{~h}(\mathrm{r}=-0.235, \mathrm{P}=0.021$; Figures $7 \mathrm{E}$ and $7 \mathrm{~F})$. The present results therefore suggested that an increase in the Th2/Th1 cytokine secretion ratio, in particular IL-10 secretion, may inhibit human breast MCF-7 cancer cell growth.

\section{Discussion}

Acetone extracts of crude pulp, peel and seeds from Psidium guajava L. induced cell cycle arrest and cell death in NB4 cells [27]. Epigallocatechin-3-gallate is a plant food-derived polyphenolic compound that has been demonstrated to significantly inhibit growth and enhance apoptosis in doxorubicin-sensitive and resistant MCF-7 cells induced by curcumin [34]. However, a direct action to cancer cells using drugs or higher concentrations of phytochemicals may cause adverse side toxic effects in vivo; therefore tumor immunotherapy is currently widely accepted as an important alternative method to treat tumors $[14,15]$. In the present study, SCM prepared in the absence or presence of 5 selected crude polysaccharides significantly inhibited MCF-7 cell viability, suggesting that cancer immunotherapy via immune cells is an effective method to treat MCF-7 cells (Figure. 6). Although the 5 selected polysaccharides did not directly affect MCF7 cell viability (Figure 5), at higher concentrations GSPS-, BBPS-, and RFLPS-treated SCM slightly inhibited MCF-7 cell viability (Figure 6). The present results therefore suggest that GSPS, BBPS and RFLPS may be further applied to treat human breast cancer via tumor immunotherapy.

In our previous study macrophage-conditioned media (MCM) cultured with the 5 polysaccharides dose-dependently inhibited prostate cancer PC-3 cell growth compared with those cultured without polysaccharides, correlating with pro-/anti-inflammatory cytokines ratios in the corresponding MCM [28]. However, the association between Th1/Th2 immune balance and tumor growth has been scarcely reported. The results of the present study provided evidence that an increase in Th2/Th1 cytokine secretion ratio in the tumor micro environment, in particular an increase in IL-10 secretion, may inhibit the viability of MCF-7 human breast cancer cells in vitro (Figure. 7). IL-10 has been reported to reduce the proliferation of MCF-7 cells, although it had no effect on apoptosis induction [35]. The immunosuppressive property of IL-10 is generally thought to support tumor growth, favoring tumor escape from immune surveillance [36], however evidence has indicated that genetic ablation of IL-10 in mice markedly increased sensitivities to chemical carcinogenesis, growth of transplanted tumors and formation of metastases [37]. IL-10 clearly serves an important function in an immunosuppressive tumor micro environment, by suppressing tumor development, growth and metastasis [37,38]. Notably, the present results provided further evidence that an increase in the Th2/Th1 cytokine secretion ratio in the tumor micro environment, in particular increased IL-10 secretion, may inhibit the growth of MCF-7 human breast cancer cells. All 5 selected polysaccharides, particularly GSPS, BBPS and RFLPS, markedly increased Th2 immune responses in the splenocytes (Figure 4), while GSPS-, BBPS-, and RFLPS-treated SCM inhibited MCF-7 cell viablity (Figure 6). Among 5 selected polysaccharides GSPS had the highest sugar content $(60.7 \%)$ (Table 1$)$ and showed the most potential to enhance the Th2 immune response in the splenocyte cultures (Figure 4), implying that the immunomodulatory function of polysaccharides might be primarily contributed by the sugar moiety. However, more evidences should be accumulated to infer the regularity of polysaccharide functions from the ratios of carbohydrate and protein contents in the polysaccharides. 
A
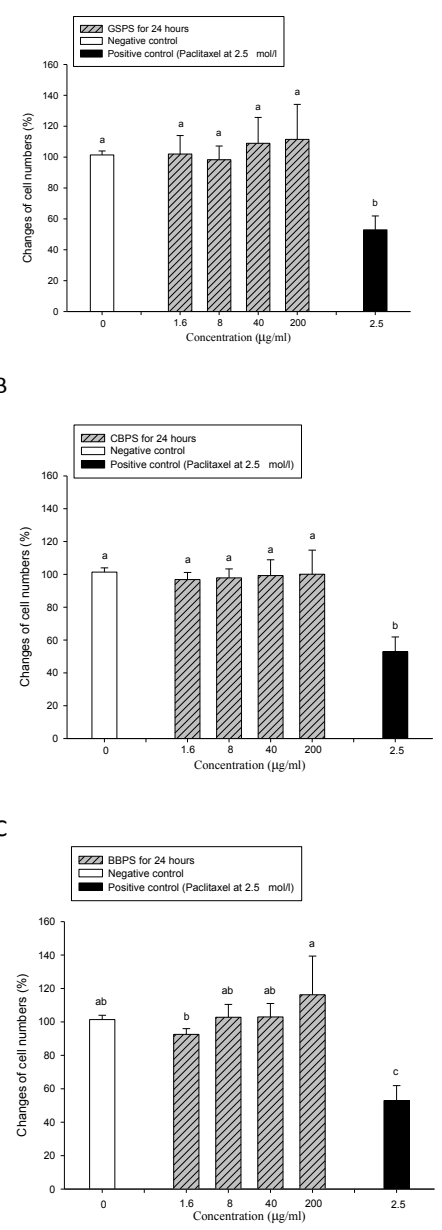
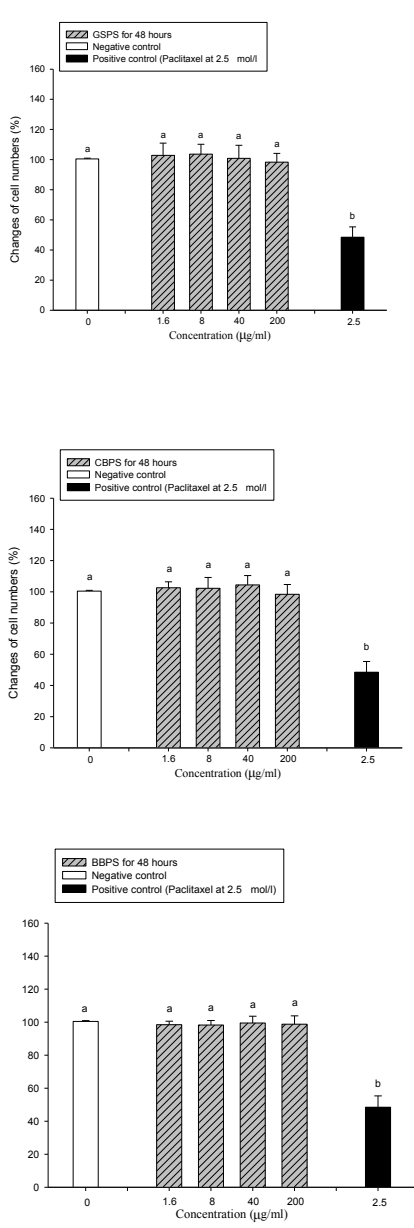

D
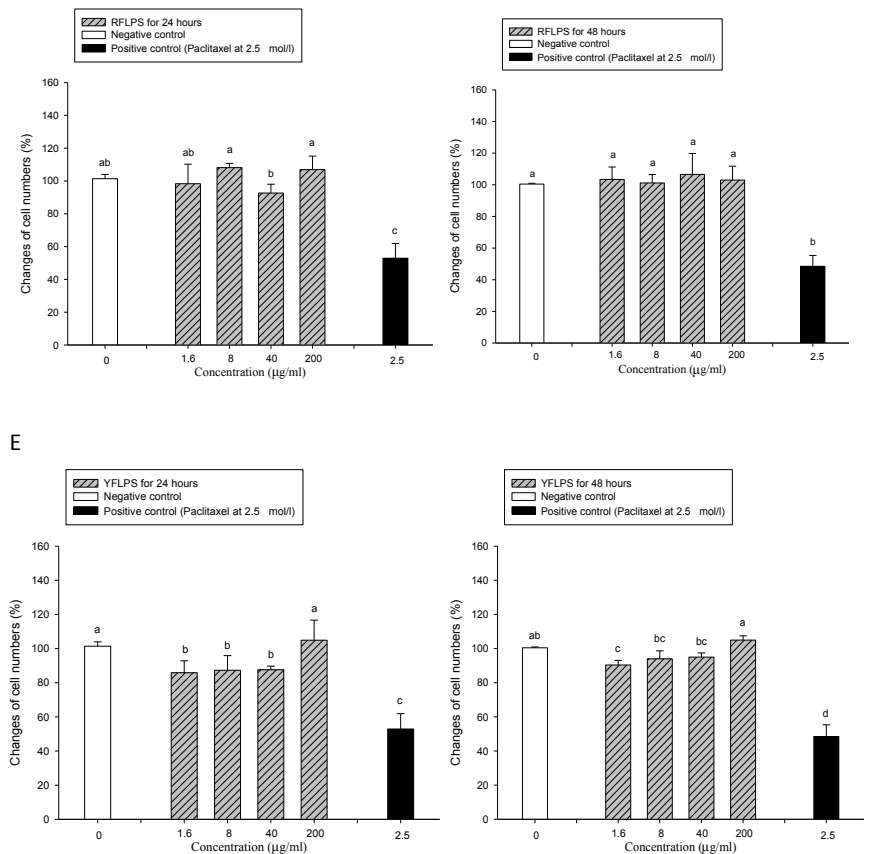

Figure 5: Effect of (A) GSPS, (B) CBPS, (C) BBPS, (D) RFLPS and (E) YFLPS administration on MCF-7 cell viability. Values are presented as the mean \pm standard deviation $(n=6)$. Bars not sharing a common small letter are significantly different $(P<0.05)$. Each cell population $\left(2 \times 10^{5}\right.$ cells $\left./ \mathrm{ml}\right)$ was treated with the polysaccharide at the indicated concentrations of $0,1.6,8,40$ and $200 \mu \mathrm{g} / \mathrm{ml}$, as well as PC (2.5 $\mathrm{mmol} / \mathrm{l}$ paclitaxel) for 24 or $48 \mathrm{~h}$. Cell viability was determined using an MTT assay. GSPS, guava seed polysaccharides; CBPS, common buckwheat polysaccharides; BBPS, bitter buckwheat polysaccharides; RFLPS, red formosa lambsquarters polysaccharides; YFLPS, yellow formosa lambsquarters polysaccharides; PC, paclitaxel positive control.

Indigestible active polysaccharides may exert their anti-cancer functions in vivo by activating immune cells (or IL-10 secreting cells) in Peyer's patches in the small intestine, even though they may not be absorbed in the gastrointestinal tract. The polysaccharides from mushroom Trametes versicolor extract, Sophora flavescens or chitosan polysaccharides are widely accepted as biological response modifiers and have been suggested as a dietary supplement to enhance the immune system of patients undergoing chemotherapy $[24,39,40]$. Different polysaccharides may possess anti-cancer properties via proapoptotic properties [41], or by stimulating macrophages, NK cells, $\mathrm{T}$ cells, and cytokine secretions $[6,8]$. All 5 selected polysaccharides, in particular GSPS, BBPS, and RFLPS, may exert their anti-cancer effects by increasing the IL-10/IL-2 (Th2/Th1) cytokine secretion ratio by $\mathrm{T}$ cells in vivo. In comparison with the association between MCF7 cell viability and IL-2 levels, IL-10 levels and IL-10/IL-2 cytokine secretion ratios (Figure 7), there were no significant differences between treatments for $24 \mathrm{~h}$ or $48 \mathrm{~h}$. This is because the MCF-7 cell viability treated with SCM for $48 \mathrm{~h}$ just slightly decreased as compared to that treated for $24 \mathrm{~h}$ (Figure 6). The results of the present study have provided a potential alternative choice to treat cancer cells with selected polysaccharides, presenting an opportunity for future studies to develop novel anticancer agents. GSPS, BBPS and RFLPS may also be applied in the chemical and pharmaceutical sectors due to their potent biological activities [42].

The present study achieved notable results. However, there are limitations associated with the present study. The in vitro study adopted SCM, which was prepared using mouse primary splenocytes to treat MCF-7 human breast cancer cells. Although the structure of the majority of cytokines between the mouse and human are similar and interactive, genetic differences between the two species may mean that human cytokines may behave differently to the mouse cytokines used in the present study. In the absence of data with additional cell lines we cannot evaluate if the observed effects are unique to the MCF-7 line, or if the results can be generalized. In addition, effects of Th1/Th2 immune balance on the growth of tumor cells in the tumor microenvironment may vary dramatically with different stages of carcinogenesis. We supposed that in the beginning of carcinogenesis Th1 inclination in the 
(A)

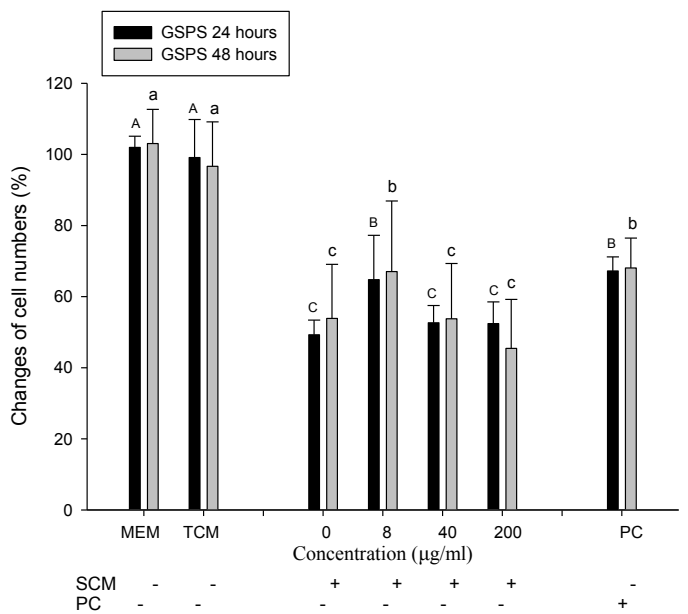

(C)

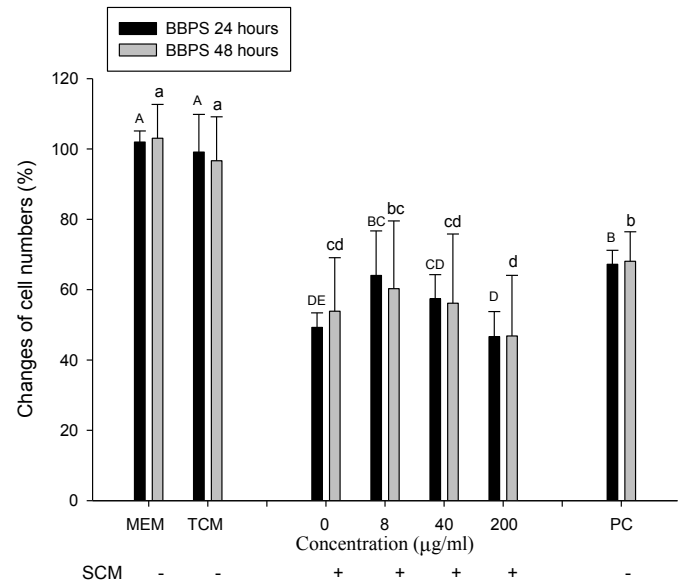
$\mathrm{SCM}_{\mathrm{PC}}$

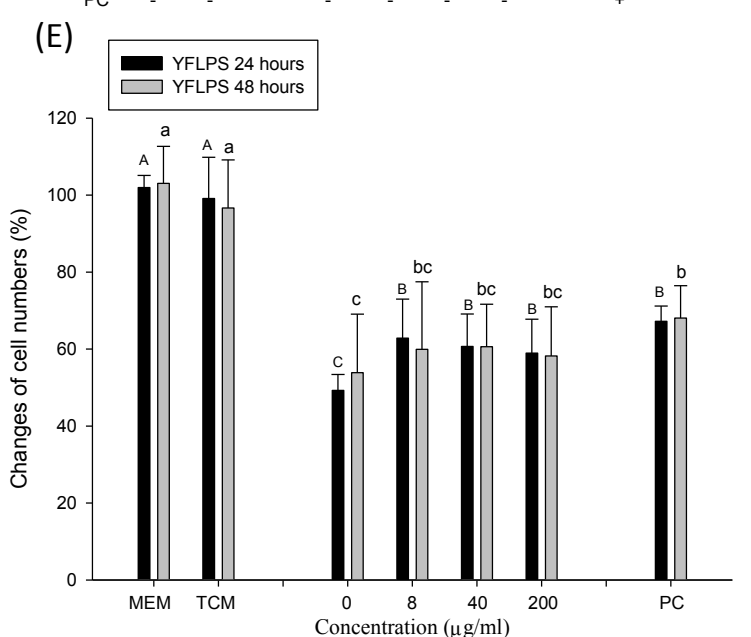

SCM
(B)

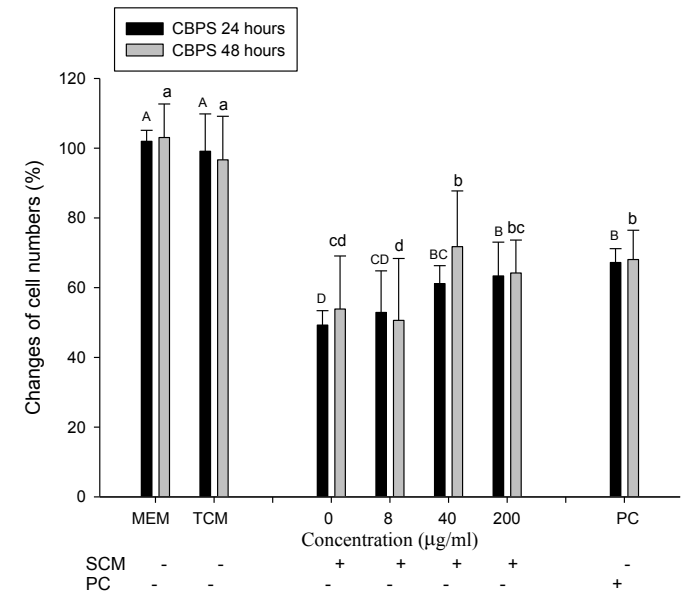

(D)

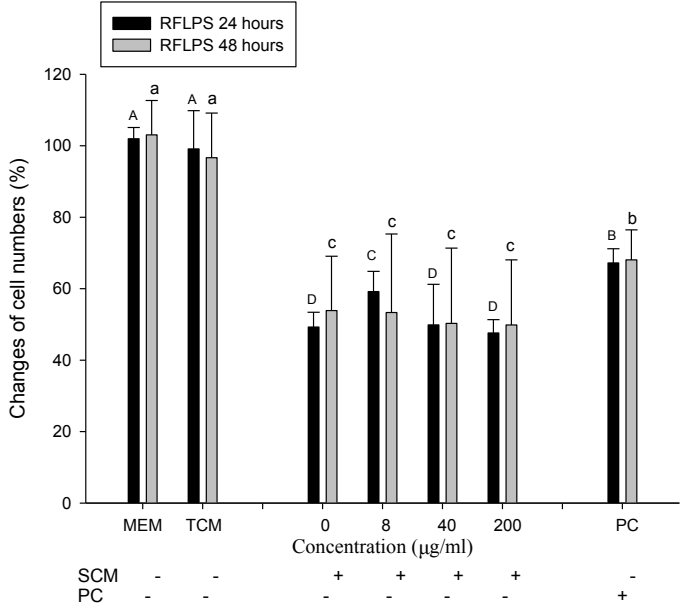

Figure 6: Effect of SCM cultured with (A) GSPS, (B) CBPS, (C) BBPS, (D) RFLPS and (E) YFLPS on the growth of breast cancer MCF-7 cells. MCF-7 cells (2 $\times 10^{5}$ cells $/ \mathrm{ml}$ ) were treated with SCM for 24 or $48 \mathrm{~h}$. Values are presented as the mean \pm standard deviation $(n=6)$. Bars at the same incubation time not sharing a common letter are significantly different $(P<0.05)$. SCM, splenocyte-conditioned media; GSPS, guava seed polysaccharides; CBPS, common buckwheat polysaccharides; BBPS, bitter buckwheat polysaccharides; RFLPS, red formosa lambsquarters polysaccharides; YFLPS, yellow formosa lambsquarters polysaccharides; PC, paclitaxel positive control; MEM, minimum essential medium/Earle's balanced salts solution; TCM, tissue culture medium; SCM were cultured with 5 selected polysaccharides at the indicated concentrations of $0,8,40$ and $200 \mu \mathrm{g} / \mathrm{ml}$, respectively. 
A

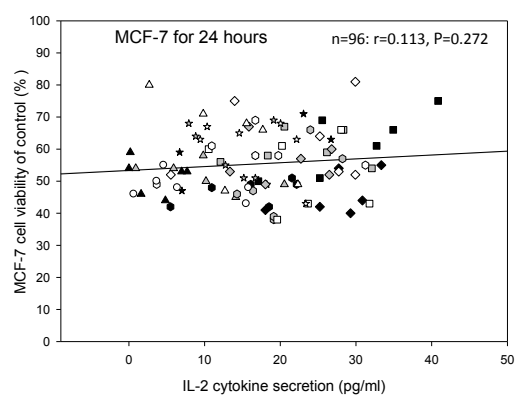

C

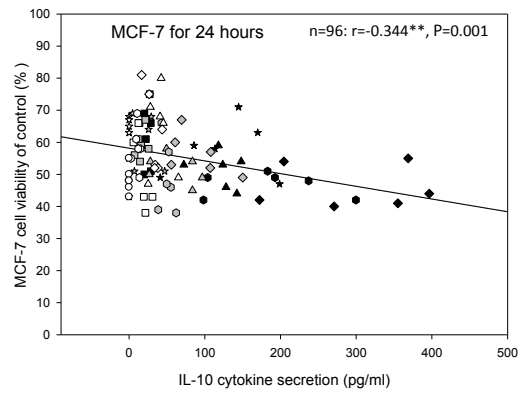

$\mathrm{E}$

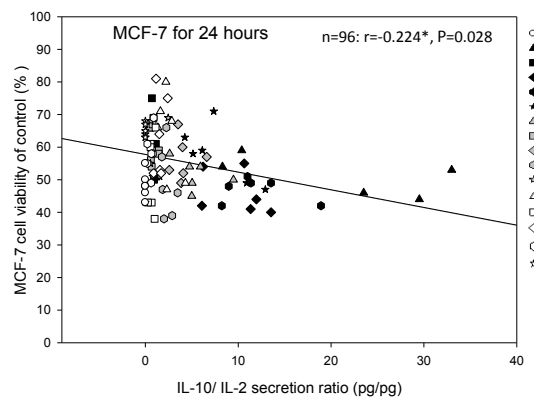

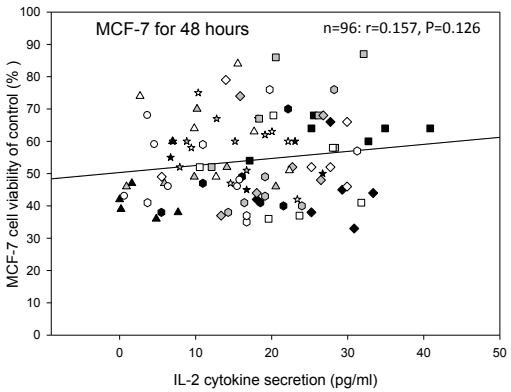

D
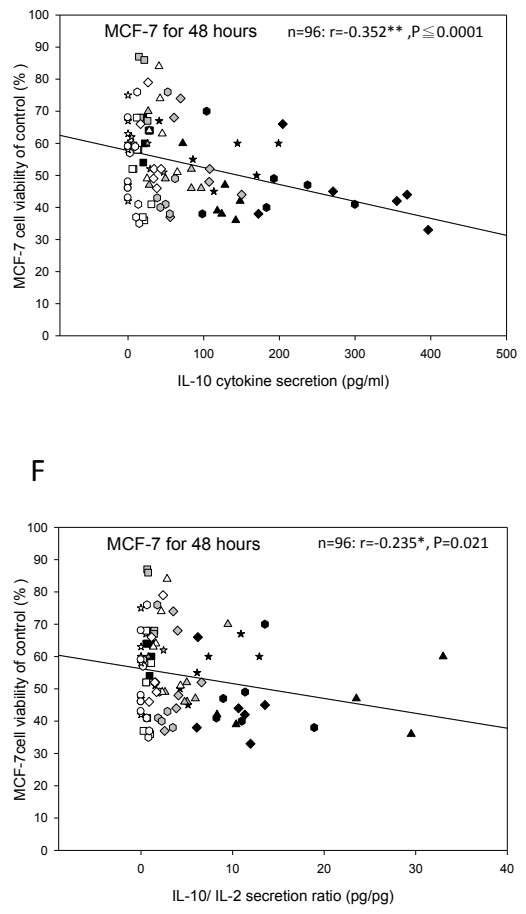

Figure 7: The association between breast cancer MCF-7 cell viability and (A,B) IL-2 levels, (C,D), IL-10 levels and (E,F) IL-10/IL-2 cytokine secretion ratios in the corresponding SCM incubated for 24 or $48 \mathrm{~h}$. ${ }^{*} \mathrm{P}<0.05$; ${ }^{* *} \mathrm{P}<0.001$. IL, interleukin; SCM, splenocyte-conditioned media cultured with 5 selected polysaccharides at the indicated concentrations of $0,8,40$ and $200 \mu \mathrm{g} / \mathrm{ml}$, respectively. The symbols in the graphs represent that the 5 selected polysaccharides at different concentrations were added to each individual SCM, respectively.

tumor microenvironment may favor to remove tumor cells via boosting immune surveillance. In contrast, in the late stage of carcinogenesis Th2 inclination in the tumor microenvironment may suppress tumor cells by inhibiting inflammation and angiogenesis. More evidences should be accumulated to clarify the relationship between cancer cell growth and Th1/Th2 immune balance in the tumor microenvironment. The study is exclusively an in vitro study. Without in vivo results we cannot determine if any of the in vitro effects are relevant in vivo. To be more useful, in vivo studies will be performed in the future. Even though the chemical information of the 5 selected crude polysaccharides has been partially analysed [28], particular characterizations and anti-cancer mechanisms of the 5 selected polysaccharide fractions remain to be further studied.

Overall, in the present study all 5 selected crude polysaccharides, in particular GSPS, BBPS and RFLPS, significantly increased the
IL-10/IL-2 cytokine secretion ratios, suggesting that these crude polysaccharides exhibited a Th2-inclination property. Treatments with SCM prepared in the absence or presence of selected polysaccharides significantly inhibited MCF-7 cell viability. GSPS, BBPS-, and RFLPS-treated SCM slightly enhanced the inhibitory effect of $2.5 \mu \mathrm{M}$ paclitaxel against MCF-7 cell viability. There were negative correlations between MCF-7 cell viability and IL10 cytokine secretion levels, as well as the IL-10/IL-2 (Th2/Th1) cytokine secretion ratio in the corresponding SCM. The present results suggested that an increased Th2/Th1 cytokine secretion ratio, in particular an increase in IL-10 secretion by immune cells including $\mathrm{T}$ lymphocytes, may inhibit MCF-7 cell growth in the tumor microenvironment. GSPS, BBPS and RFLPS may be further applied to treat human breast cancer via tumor immunotherapy by increasing the Th2/Th1 cytokine secretion ratio. 
Citation: Lin HC, Lin JY (2017) Splenocyte-Conditioned Media Inhibit Breast Cancer MCF-7 Cell Growth, Associated with Increased Th2/Th1 Cytokine Secretion Ratio in the Media using Five Selected Polysaccharides. J Immuno Biol 2: 121.doi: 10.4172/2476-1966.1000121

Page 14 of 14

\section{Conflict of Interests}

The authors declared no conflict of interest.

\section{Acknowledgement}

The present study was supported by the Ministry of Science and Technology, Taipei, Taiwan, R.O.C. (grant no. NSC102-2313-B-005-033-MY3).

\section{References}

1. Ferlay J, Shin HR, Bray F, Forman D, Mathers C, et al. (2010) Parkin, Estimates of worldwide burden of cancer in 2008: GLOBOCAN 2008. Int J Cancer 127 2893-2917.

2. Duo J, Ying GG, Wang GW, Zhang L (2012) Quercetin inhibits human breast cancer cell proliferation and induces apoptosis via $\mathrm{Bcl}-2$ and $\mathrm{Bax}$ regulation. Mol Med Rep 5: 1453-1456.

3. Collaborative Group on Hormonal Factors in Breast Cancer (2012) Menarche menopause, and breast cancer risk: individual participant meta-analysis, including 118,964 women with breast cancer from 117 epidemiological studies. Lancet Oncol 13: 1141-1151.

4. DeSantis C, Ma J, Bryan L, Jemal A (2014) Breast Cancer Statistics, 2013. CA Cancer J Clin 64: 52-62.

5. DeSantis C, Siegel R, Bandi P, Jemal A (2011) Breast cancer statistics, 2011 CA Cancer J Clin 61 409-418.

6. Chen J, Zhang XD, Jiang Z (2013) The application of fungal beta-glucans for the treatment of colon cancer. Anticancer Agents Med Chem 13: 725-730.

7. Liao $\mathrm{CH}$, Lin JY (2013) Purified active lotus plumule (Nelumbo nucifera Gaertn) polysaccharides exert anti-inflammatory activity through decreasing toll-like receptor-2 and -4 expressions using mouse primary splenocytes. J Ethnopharmacol 147: 164-173.

8. Patel S, Goyal A, (2012) Recent developments in mushrooms as anti-cancer therapeutics: a review. 3 Biotech 2: 1-15.

9. Liu CJ, Lin JY (2014) Protective effects of strawberry and mulberry fruit polysaccharides on inflammation and apoptosis in murine primary splenocytes. J Food Drug Anal 22: 210-219.

10. Guo X, Zhu K, Zhang H, Yao H (2007) Purification and characterization of the antitumor protein from Chinese tartary buckwheat (Fagopyrum tataricum Gaertn.) water-soluble extracts. J Agric Food Chem 55: 6958-6961.

11. Guo X, Zhu K, Zhang H, Yao H (2010) Anti-tumor activity of a novel protein obtained from tartary buckwheat. Int J Mol Sci 11: 5201-5211.

12. He N, Yang X, Jiao Y, Tian L, Zhao Y. (2012) Characterisation of antioxidant and antiproliferative acidic polysaccharides from Chinese wolfberry fruits. Food Chem 133: 978-989.

13. He N, Shi X, Zhao Y, Tian L, Wang D, et al. (2013) Inhibitory effects and molecular mechanisms of selenium-containing tea polysaccharides on human breast cancer MCF-7 cells. J Agric Food Chem 61: 579-588.

14. Strebhardt K, Ullrich A (2008) Paul Ehrlich's magic bullet concept: 100 years of progress. Nat Rev Cancer 8: 473-480

15. Waldmann TA (2003) Immunotherapy: past, present and future. Nat Med 9 269-277.

16. Palucka K, Banchereau J, Dendritic-cell-based therapeutic cancer vaccines, Immunity 39: 38-48.

17. Cohen MH, Chen H, Shord S, Fuchs C, He K, et al. (2013) Approval summary: Cetuximab in combination with cisplatin or carboplatin and 5-fluorouracil for the first-line treatment of patients with recurrent locoregional or metastatic squamous cell head and neck cancer. Oncologist 18: 460-466.

18. de Claro RA, McGinn K, Kwitkowski V, Bullock J, Khandelwal A, et al. (2012) U.S. Food and Drug Administration approval summary: brentuximab vedotin for the treatment of relapsed Hodgkin lymphoma or relapsed systemic anaplastic large-cell lymphoma. Clin Cancer Res 18: 5845-5849.

19. Demko S, Summers J, Keegan P, Pazdur R (2008) FDA drug approval summary: alemtuzumab as single-agent treatment for B-cell chronic lymphocytic leukemia. Oncologist 13: 167-174.

20. Coventry BJ, Ashdown ML, (2012) The $20^{\text {th }}$ anniversary of interleukin-2 therapy: bimodal role explaining longstanding random induction of complete clinical responses. Cancer Manag Res 4: 215-221.
21. Dranoff G (2004) Cytokines in cancer pathogenesis and cancer therapy. Nat Rev Cancer 4: 11-22

22. Dunn GP, Koebel CM, Schreiber RD (2006) Interferons, immunity and cancer immunoediting. Nat Rev Immunol 6: 836-848.

23. Lasfar A, Abushahba W, Balan M, Cohen-Solal KA, (2011) Interferon lambda: a new sword in cancer immunotherapy. Clin Dev Immunol 2011: 349575.

24. Wenner CA, Martzen MR, Lu H, Verneris MR, Wang H, et al. (2012) Polysaccharide-K augments docetaxel-induced tumor suppression and antitumor immune response in an immunocompetent murine model of human prostate cancer. Int J Oncol 40: 905-913.

25. Liao CH, Lin JY (2011) Lotus (Nelumbo nucifera Gaertn) plumule polysaccharide protects the spleen and liver from spontaneous inflammation in non-obese diabetic mice by modulating pro-/anti-inflammatory cytokine gene expression. Food Chem. 129 (2011) 245-252.

26. Liao CH, Lin JY (2012) Purification, partial characterization and antiinflammatory characteristics of lotus (Nelumbo nucifera Gaertn) plumule polysaccharides. Food Chem 135: 1818-1827.

27. Bontempo P, Doto A, Miceli M, Mita L, Benedetti R, et al. (2012) Psidium guajava L. anti-neoplastic effects: induction of apoptosis and cell differentiation. Cell Prolif 45: 22-31.

28. Lin HC, Lin JY (2016) Immune cells conditioned media suppress prostate cancer PC-3 cell growth correlating with decreased pro-/anti-inflammatory cytokine ratios in the media using five selected crude polysaccharides. Integr Cancer Ther 15: NP13-NP25.

29. Dubois M, Gilles K, Hamilton JK, Rebers PA, Smith F (1951) A colorimetric method for the determination of sugars. Nature 168: 167.

30. Smith PK, Krohn RI, Hermanson GT, Mallia AK, Gartner FH, et al. (1985) Measurement of protein using bicinchoninic acid. Anal Biochem 150: 76-85.

31. Ku CM, Lin JY (2013) Anti-inflammatory effects of 27 selected terpenoid compounds tested through modulating Th1/Th2 cytokine secretion profiles using murine primary splenocytes. Food Chem 141: 1104-1113.

32. Lin BF, Chiang BL, Lin JY (2005) Amaranthus spinosus water extract directly stimulates proliferation of B lymphocyte in vitro Int Immunopharmacol 5: 711-722.

33. Gligorov J, Lotz JP, (2004) Preclinical pharmacology of the taxanes: implications of the differences. Oncologist 9: 3-8.

34. Wang S, Chen R, Zhong Z, Shi Z, Chen M, et al. (2014) Epigallocatechin3-gallate potentiates the effect of curcumin in inducing growth inhibition and apoptosis of resistant breast cancer cells. Am J Chin Med 42: 1279-1300.

35. Hojman P, Dethlefsen C, Brandt C, Hansen J, Pedersen L, et al. (2011) Exercise-induced muscle-derived cytokines inhibit mammary cancer cell growth. Am J Physiol Endocrinol Metab 301: E504-E510.

36. Sredni B, Weil M, Khomenok G, Lebenthal I, Teitz S, et al. (2004) Ammonium trichloro(dioxoethylene-o,o')tellurate (AS101) sensitizes tumors to chemotherapy by inhibiting the tumor interleukin 10 autocrine loop. Cancer Res 64: 1843-1852.

37. Tanikawa T, Wilke CM, Kryczek I, Chen GY, Kao J, et al. (2012) Interleukin-10 ablation promotes tumor development, growth, and metastasis. Cancer Res 72: $420-429$.

38. Lin JY, Tang CY (2007) Interleukin-10 administration inhibits TNF- $\alpha$ and IL-1 but not IL-6 secretion of LPS-stimulated peritoneal macrophages. J Food Drug Anal 15: 48-54.

39. Bai L, Zhu LY, Yang BS, Shi LJ, Liu Y, et al. (2012) Antitumor and immunomodulating activity of a polysaccharide from Sophora flavescens Ait. Int J Biol Macromol 51: 705-709.

40. Ma JX, Qian L, Zhou Y (2015) Stimulation effect of chitosan on the immunity of radiotherapy patients suffered from lung cancer. Int J Biol Macromol 72 : 195-198.

41. Parzonko A, Makarewicz-Wujec M, Jaszewska E, Harasym J, KozłowskaWojciechowska M (2015) Pro-apoptotic properties of $(1,3)(1,4)-\beta$-D-glucan from Avena sativa on human melanoma HTB-140 cells in vitro. Int $\mathrm{J}$ Biol Macromol 72: 757-763.

42. Kagimura FY, da Cunha MA, Barbosa AM, Dekker RF, Malfatti CR (2015) Biological activities of derivatized d-glucans: A review. Int J Biol Macromol 72 588-598. 